\title{
New dates for the Makekur (FOH) Lapita pottery site, Arawe Islands, New Britain, Papua New Guinea
}

\author{
Jim Specht and Chris Gosden
}

\begin{abstract}
Estimates for the start of Lapita pottery in the Bismarck Archipelago, Papua New Guinea, have ranged from 3550-3450 cal. BP to 3300-3200 cal. BP. These estimates in turn overlap date ranges of 3480-3150 cal. BP and of 3360-3040 cal. BP for the W-K2 volcanic eruption in northern New Britain and reoccupation of the area by people with Lapita pottery (Petrie and Torrence 2008, 95.4 per cent probability). Here we review issues surrounding existing ${ }^{14} \mathrm{C}$ dates for the start of Lapita pottery throughout the archipelago and present six new dates for the Makekur Lapita site in the Arawe Islands. Based on a non-Bayesian assessment of the dates, we estimate a possible start of Lapita pottery around 3250-3150 cal. BP, at the late end of the ranges for the Witori eruption and reoccupation of the Willaumez Peninsula and close to initial dates for the Lapita expansion into Remote Oceania. Refinement of this estimate for the introduction of pottery to the Bismarck Archipelago through application of Bayesian statistics requires resolution of issues relating to existing dates and pottery analyses, and incorporation of results from current and planned redating programs of Lapita pottery sites within the archipelago.
\end{abstract}

\section{Introduction}

Over the last 20 years, progress has been made in dating the origins and subsequent dispersal of Lapita pottery in the Western Pacific Islands, particularly across the Near/Remote Oceania boundary (Bedford 2015; Sheppard 2011). Recent dating programs throughout the western part of Remote Oceania have suggested that this expansion began around 3000 or so years ago, slightly later than previously accepted (Burley et al. 2015; Clark and Anderson 2009; Galipaud and Swete Kelly 2007; Green and Jones 2008; Green et al. 2008; Jones et al. 2007; Nunn and Petchey 2013; Petchey et al. 2014, 2015; Sheppard et al. 2015). This has led to calls for reconsideration of the starting date for Lapita pottery in the Bismarck Archipelago of Papua New Guinea (Bedford 2015; Petchey et al. 2015:241; Sheppard et al. 2015:34-35), thus reviving the question of whether there was a period during which the Lapita Cultural Complex developed within the archipelago before the pottery-makers dispersed into Remote Oceania (e.g. Sheppard 2011; Specht 2007; Specht et al. 2014). 
The starting date for Lapita pottery in the Bismarck Archipelago (Figure 9.1) is poorly resolved. Working with limited data, Kirch and Hunt (1988) initially estimated the starting date in the Bismarck Archipelago at 3550-3450 cal. BP (Figure 9.2). With the accumulation of radiocarbon dates this has been adjusted to 3300-3200 cal. BP (Specht and Gosden 1997; Summerhayes 2007, 2010), and 3450-3350 cal. BP (Specht 2007). These estimates based on 'eyeballing' the data used different protocols for sample selection and calibration procedures. A later study (Denham et al. 2012), applying Bayesian statistics, compared a set of terrestrial-only samples with one combining terrestrial and marine samples, and concluded that pottery appeared in the Mussau Islands around 3470-3250 cal. BP (68.2 per cent probability). This was slightly earlier than the rest of the archipelago, where the appearance of pottery was placed around 3360-3240 cal. BP. As those authors stated, the spread of Lapita pottery within the Bismarck Archipelago cannot be determined through these ranges, as the Mussau date range does not appear to be significantly older than in the rest of the archipelago (Denham et al. 2012:44). This study was based on assumptions about the origins and stylistic development of Lapita pottery in the Mussau Islands that are open to question (cf. Summerhayes 2010:20-23). A more recent study (Rieth and Athens 2017) also applied a Bayesian analysis, using several models that combined and separated out marine shell and plant samples. They concluded that Mussau could have been settled earlier than the rest of the archipelago but could not discount contemporaneous settlement (Rieth and Athens 2017:8, Figure 4). Their model, combining marine shell and short-lived nutshell samples, placed initial Lapita pottery occupation as likely 3304-3177 cal. BP (68.2 per cent).

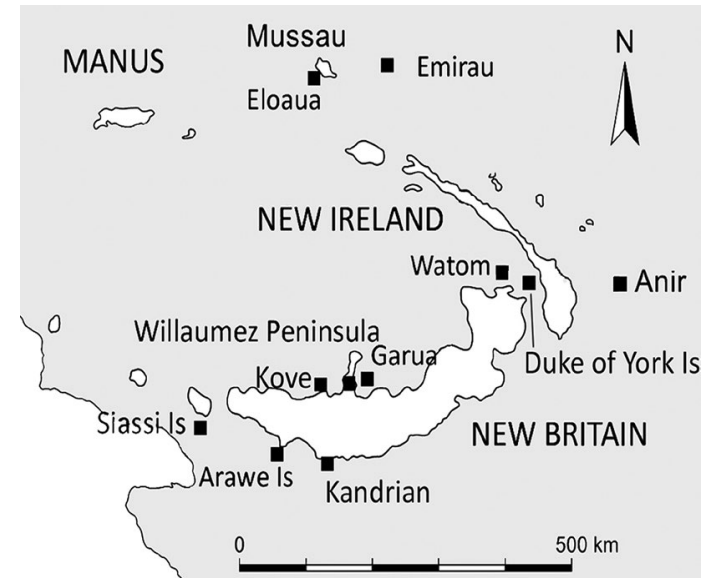

Figure 9.1. Location map of the Arawe Islands, Papua New Guinea and other Bismarck Archipelago Lapita pottery sites and island groups mentioned in the text and tables. Source: Drawing by J. Specht.

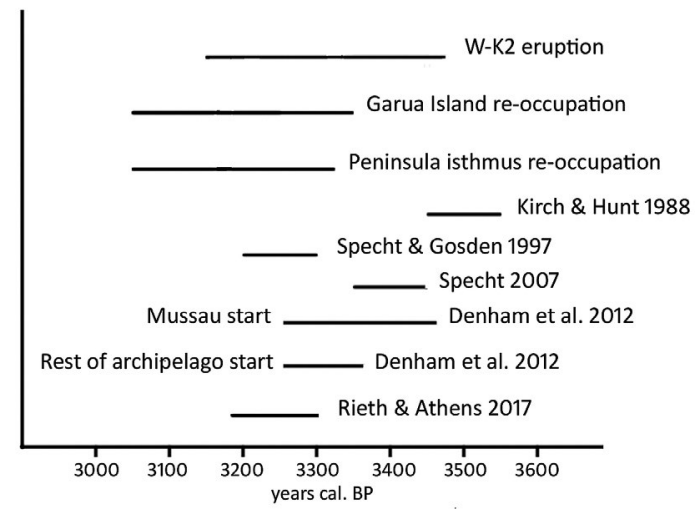

Figure 9.2. Date ranges proposed for the start of Lapita pottery (68.2 per cent) in the Bismarck Archipelago, Papua New Guinea, in relation to the W-K2 volcanic event and the reoccupation of Garua Island and the Willaumez Peninsula isthmus (95.4 per cent), New Britain.

Source: Prepared by J. Specht from the sources cited.

The ranges derived by Denham et al. and Rieth and Athens fall within or overlap with that of 3480-3150 cal. BP for the W-K2 volcanic eruption in northern New Britain (Figure 9.2). This range is based on a Bayesian analysis of a large suite of dates on charred wood and nutshell samples from Willaumez Peninsula and Garua Island, New Britain (Petrie and Torrence 2008: Table 5, range listed at 95.4 per cent probability; the 63.2 per cent value provided by that earlier version of OxCal was 3420-3260 cal. BP: C. Petrie pers. comm. 4 June 2017). This event deposited c. $50 \mathrm{~cm}$ of tephra over the island and peninsula and would have resulted in extensive destruction and abandonment of the area. Reoccupation occurred around 3330-3040 and 3360-3040 cal. BP (95.4 per cent) for the peninsula and island respectively (Petrie and Torrence 2008: Table 6). These ranges establish a maximum age for Lapita pottery in the region, 
which occurs here only in the palaeosol formed on the W-K2 tephra (Specht et al. 1991:284, 287). These results led Torrence (2016:7) to suggest that the W-K2 event and the start of Lapita pottery were essentially 'synchronous', though they potentially open a wide window between the appearance of pottery in the archipelago and the dispersal into Remote Oceania.

A problem with these attempts to define a starting date for Lapita pottery has been a reluctance to apply rigorous 'chronometric hygiene' (Spriggs 1989) to the various date sets. One exception to this was the reassessment of dates for Lapita pottery in the Bismarck Archipelago that excluded all marine shell samples on the grounds that there were too few locality-specific $\Delta \mathrm{R}$ values to enable meaningful calibrations (Specht 2007: Table 1), though the 26 plant samples used were only lightly vetted. Here we apply more rigorous culling protocols for both marine and terrestrial samples than have been used in previous studies, taking advantage of locality-specific $\Delta \mathrm{R}$ values for parts of the archipelago (Petchey and Ulm 2012). The study incorporates six new AMS dates on plant materials from the Makekur Lapita site in New Britain (Gosden and Webb 1994). Combining these new dates with the existing ones throughout the Archipelago, this chapter concludes that the starting date for Lapita pottery in the Bismarck archipelago could be younger than existing estimates and close to the initial dates for the settlement of Remote Oceania.

\section{Materials and methods}

Radiocarbon dates used in this chapter have been calibrated in OxCal 4.2.4 (Bronk Ramsey 2009) using the IntCal13 and Marine13 curves (Reimer et al. 2013). Within the main text, age ranges are rounded to the nearest five- or 10-year interval and are cited at 68.2 per cent probability to 'reflect the central tendency in the probability distributions' (Denham et al. 2012:43), except where a quoted range was published elsewhere only at 95.4 per cent probability. The tables show both probability distributions. Significance tests for comparing date results, and calculation of pooled means were carried out using Calib 7.0.2.

We employ an 'eyeballing' approach rather than a Bayesian statistical analysis, which we believe would be premature at this stage for several reasons. As Bronk Ramsey (2009:358) observes, 'any analysis of this [Bayesian] kind is very strongly dependent on the information that goes into it', noting:

however much statistical analysis we do, ${ }^{14} \mathrm{C}$ dates are still reliant on the underlying assumptions of the ${ }^{14} \mathrm{C}$ method - any problems with the samples, their contexts, their associations with each other, or with the calibration curve, will have implications for the accuracy of our chronologies. (2009:358)

This warning is relevant in the present context as there are issues of sample material, context, association and calibration that have to be resolved before there can be consensus on the corpus of dates to be used.

A literature search revealed over $120{ }^{14} \mathrm{C}$ dates for Lapita pottery contexts at 40 sites in the Bismarck Archipelago (Appendix 9.1). This list was initially reduced according to the excavator's commentary, and whether a date was unlikely to relate to the beginning or early stage of Lapita pottery. Any sample with a calibrated range falling below $3000 \mathrm{cal}$. BP at its upper limit was rejected on the grounds that all existing proposals place the start well before that time. As pottery production was introduced into the Bismarck Archipelago from Island Southeast Asia (ISEA), its appearance in the archipelago cannot be older than putative ancestral sites in ISEA. Several very old dates for Lapita pottery with ranges exceeding $3600 \mathrm{cal}$. BP were therefore excluded as unlikely to be relevant. The next stage in the culling process revealed all the problems encountered in the application of 'chronometric hygiene' (Spriggs 1989) and 'chronometric 
flossing' (Kirch 2001:204) to Southeast Asian and Pacific radiocarbon dates (cf. Allen and Huebert 2014; Allen and Wallace 2007; Anderson 1991, 1995; Clark et al. 2010; Hogg et al. 1998; Spriggs 1990, 1996, 2003; Spriggs and Anderson 1993). Here we discuss some general issues and provide specific comments for each sample in Appendix 9.1.

\section{Reporting issues}

With the exception of the comprehensive presentation of the Mussau results (Kirch 2001: Chapter 10, Appendix 10.1), the manner in which many dates have been reported raises issues involving inadequate or missing information on sample context and condition, association with culturally modified items, lack of clarity as to what the date is thought to refer to and suitability of the dating material, particularly its identification and possibility of in-built age (cf. Bayliss 2015; Dye 2015). Few samples were from culturally modified items that represent an event (e.g. house construction) and most are at best average age assessments for the dated context. Several sites have chronologies based on three or fewer dates that were often selected for reasons that are not made explicit, and it is unclear in some cases whether the dated sample refers to what the excavator considered to be the initial occupation level of the site.

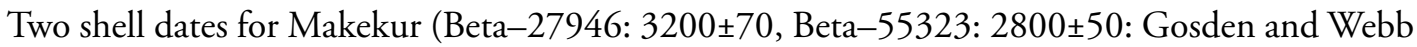
1994:42; Specht and Gosden 1997: Appendices 1,3) were not reported as conventional ${ }^{14} \mathrm{C}$ ages, but as 'radiocarbon years before present' (RCYBP), without adjustment for $\delta^{13} \mathrm{C}$ fractionation (Stuiver and Polach 1977). Summerhayes (2001a: Table 3) provides an adjusted age for Beta55323 (3230 \pm 70 ), but not for Beta-27946. If Beta-27946 is adjusted according to Stuiver and Polach (1977: Figure 1), the resulting calibrated range is too old to be relevant.

\section{Plant samples}

Taxonomic identification of wood and charcoal samples is essential to eliminate those likely to have in-built age, where the sample may refer to a growth stage substantially predating the archaeological event being investigated. Ideally, plant materials with minimum in-built age should be selected for dating, such as plant parts (e.g. leaves, fruits and nuts) that have growth cycles lasting a few months rather than many years, though this is not always possible. No charcoal samples from Lapita contexts in the archipelago have been identified to any taxonomic level, though Kirch (2001: Table 4.2) provides several wood identifications. Posts B1 (ANU-5790) and B2 (ANU-5791) from the ECA Area B structure are from Intsia bijuga (Colebr.) O. Kuntze, a tree that grows to $25 \mathrm{~m}$ height and reaches maturity in $75-80$ years. It is fast-growing in the early stages, reaching $150 \mathrm{~mm}$ diameter in eight years, and increases in diameter by $14-18 \mathrm{~mm}$ per annum (Thaman et al. 2006). Post B2 was $180 \mathrm{~mm}$ in diameter (Kirch 2001: Table 4.2) and is unlikely to have significant in-built age; the diameter of Post B1 is not given. As the two posts gave virtually the same ${ }^{14} \mathrm{C}$ age, we assume that Post $\mathrm{B} 1$ also has little in-built age. Post C3 (Beta-30686) is identified as Diospyros sp. This is a speciose genus and without specific identification, it is impossible to discuss growth rates. Unidentified stake B30 (Beta-20452) is only $30 \mathrm{~mm}$ in diameter, and so is assumed to have little in-built age. Among the plant samples with short growth cycles, usually less than one year, are Cocos nucifera endocarp at SAC on Watom Island and ECA in the Mussau Islands (Anson et al. 2005: Table 6; Kirch 2001: Chapter 10, Beta-20451), Canarium endocarps for Makekur (this study), and probable Canarium sp. endocarps for Garua Island and Willaumez Peninsula (Petrie and Torrence 2008: Tables 2, 3; Torrence and Stevenson 2000: Table 1). 


\section{Calibration of marine samples}

Many dates in the Bismarck Archipelago were on marine shells, reflecting the absence or scarcity of charred plant materials in many sites, and the fact that many samples were run before the AMS technique became widely available for processing milligram-sized plant samples. This heavy reliance on marine shells poses a serious problem, as the marine reservoir of ${ }^{14} \mathrm{C}$ (Stuiver and Braziunas 1993) varies across the Bismarck and Solomon Seas within which the archipelago is situated and has oscillated through time (Edwards et al. 1993; McGregor et al. 2008; Petchey and Ulm 2012). Calculation of $\Delta \mathrm{R}$ offset values to compensate for this variability has progressed in recent years, but major gaps and issues remain. Petchey and Ulm (2012: Figures 1, p. 55) have summarised the results so far, dividing the archipelago and neighbouring waters into six $\Delta R$ regions; two island groups (Mussau and Anir) are not assigned to a specific region but are listed separately with their own local $\Delta \mathrm{R}$ values (Table 9.1).

Region 1 (38 \pm 14 years) is based on four sets of live-collected, pre-1950 shells from the north-east and south-west parts of the Solomon Sea that form a tight group of values. Region $2(273 \pm 216$ years), in contrast, is derived from widely divergent calculations based on ${ }^{14} \mathrm{C}$ and $\mathrm{U} / \mathrm{Th}$ dates on corals or ${ }^{14} \mathrm{C}$ dates on pre-1950 live-collected shells from the Huon Peninsula coast of New Guinea (Petchey and Ulm 2012: Tables 1, 3). One coral sample, Sialum (a) $(-199 \pm 50$ years) is suspect as it appears to have been collected around 1955 and is likely to reflect the impact of nuclear bomb testing (F. Petchey pers. comm. 4 March 2016). Region 3 (314 74 years) is specific to Watom Island at the eastern end of New Britain and is based on paired archaeological charcoal and marine shell samples (Petchey et al. 2005). Although Watom Island is close to Rabaul and the Duke of York Islands that are placed in Region 1, the Watom value is markedly different. Region 4 (18 100 years) embraces Muschu Island and the Ramu River delta on the western side of the archipelago and, as in Region 2, is based on ${ }^{14} \mathrm{C}$ and $\mathrm{U} / \mathrm{Th}$ dates on corals and ${ }^{14} \mathrm{C}$ dates on pre-1950 live-collected shells. Region 5 ( $40 \pm 19$ years) covers the northern and southern ends of the Bismarck Sea. As no samples from the northern (Manus) end are included here, calibrations for the Boduna (FEA) site off the northern coast of New Britain employ the value for nearby Kimbe Bay ( $45 \pm 19$ years). Region 6 ( $141 \pm 131$ years) embraces the northern end of New Ireland and New Hanover Island, and the value is based on pre-1955 live-collected shells. It does not include the Mussau Islands, for which Kirch (2001: Chapter 10) calculated four $\Delta \mathrm{R}$ values from paired archaeological charcoal and shells that Petchey and Ulm (2012: Figure 1) recalculate as $-293 \pm 92$ years. Finally, Table 9.1 includes a value for the Anir Islands $(-69 \pm 51$ years) derived from two archaeological pairs of charcoal and shells (Summerhayes 2007:154).

Table 9.1. $\Delta \mathrm{R}$ offsets for localities in the Bismarck and Solomon seas, Papua New Guinea, based on Petchey and Ulm (2012: Figure 1, p. 55) and references as cited.

\begin{tabular}{|c|c|c|c|c|}
\hline Region & Location & Delta-R & Calculation basis & Regional value \\
\hline \multirow[t]{4}{*}{1} & Samarai & $26 \pm 34$ & pre-1950 shell & \multirow[t]{4}{*}{$38 \pm 14$} \\
\hline & Kiriwina I. & $44 \pm 17$ & pre-1950 shell & \\
\hline & Duke of Yorks & $43 \pm 68$ & pre-1950 shell & \\
\hline & Rabaul & $23 \pm 35$ & pre-1950 shell & \\
\hline \multirow[t]{4}{*}{2} & Finschhafen & $333 \pm 14$ & pre-1950 shell & \multirow[t]{4}{*}{$273 \pm 216$} \\
\hline & Sialum (a) & $-199 \pm 50$ & 1955 coral & \\
\hline & Sialum (b) & $63 \pm 65$ & ${ }^{14} \mathrm{C}$ v U/Th coral & \\
\hline & Sialum (c) & $84 \pm 53$ & ${ }^{14} \mathrm{C}$ v U/Th coral & \\
\hline \multirow[t]{2}{*}{3} & Watom (a) & $321 \pm 103$ & archaeological pair & \multirow[t]{2}{*}{$314 \pm 74$} \\
\hline & Watom (b) & $307 \pm 105$ & archaeological pair & \\
\hline
\end{tabular}




\begin{tabular}{|c|c|c|c|c|}
\hline Region & Location & Delta-R & Calculation basis & Regional value \\
\hline \multirow[t]{4}{*}{4} & Muschu (a) & $-48 \pm 74$ & ${ }^{14} \mathrm{C} \mathrm{v} \mathrm{U/Th} \mathrm{coral}$ & \multirow[t]{4}{*}{$18 \pm 100$} \\
\hline & Muschu (b) & $-159 \pm 46$ & ${ }^{14} \mathrm{C}$ v U/Th coral & \\
\hline & Muschu (c) & $70 \pm 60$ & pre-1950 shell & \\
\hline & Ramu mouth & $41 \pm 17$ & pre-1950 shell & \\
\hline \multirow[t]{3}{*}{5} & Manus I. & $18 \pm 13$ & pre-1950 shell & \multirow[t]{3}{*}{$40 \pm 19$} \\
\hline & Lou I. & $8 \pm 108$ & archaeological pair & \\
\hline & Kimbe Bay & $45 \pm 19$ & pre-1950 shell & \\
\hline \multirow[t]{3}{*}{6} & New Hanover & $111 \pm 17$ & pre-1950 shell & \multirow[t]{3}{*}{$141 \pm 131$} \\
\hline & Kavieng (a) & $365 \pm 50$ & pre-1950 shell & \\
\hline & Kavieng (b) & $305 \pm 110$ & pre-1950 shell & \\
\hline \multirow[t]{4}{*}{ Mussau } & $\mathrm{ECA} / \mathrm{B}(\mathrm{a})$ & -290 & archaeological pair & \multirow{4}{*}{$\begin{array}{c}-293 \pm 92 \text { (Petchey \& Ulm 2012: Figure 1) } \\
-320 \text { (Kirch 2001:201-204) }\end{array}$} \\
\hline & $\mathrm{ECA} / \mathrm{B}(\mathrm{b})$ & -350 & archaeological pair & \\
\hline & ECB (a) & -350 & archaeological pair & \\
\hline & ECB (b) & -370 & archaeological pair & \\
\hline Anir & Kamgot & $-69 \pm 51$ & 2 archaeological pairs & -69ェ51 (Summerhayes 2007:154) \\
\hline
\end{tabular}

Source: See references in table.

It is thus obvious that many areas of the Bismarck Archipelago do not have a locality-specific $\Delta \mathrm{R}$ value. In such cases, where the sample location falls within the boundaries of a proposed $\Delta \mathrm{R}$ region of Petchey and Ulm (2012: Figure 1), this value can be used, but the results should be treated with caution. The Arawe Islands off the south-west coast of New Britain are peripherally included within Region 2 by Petchey and Ulm (2012: Figure 1), but the neighbouring Kandrian area lies outside both this and Region 1. Consequently, no marine shell dates for Kandrian sites are included in the study. Shell dates used in calculations of local $\Delta \mathrm{R}$ values are excluded as they do not constitute independent determinations. This affects four dates for ECA and ECB in the Mussau Islands, two for ERA in the Anir Islands, and one from SAC on Watom Island (Appendix 1).

\section{Environmental/dietary influences on marine shells}

For all marine shell samples reviewed in this study, the marine contribution of ${ }^{14} \mathrm{C}$ is assumed to be 100 per cent, although local environmental and geological factors can influence the radiocarbon concentration in shells (Anderson et al. 2001:38; Dye 1994; Petchey and Clark 2010; Tanaka et al. 1986). Most of the Lapita pottery sites reviewed here are located on palaeo-reef limestone platforms, and in areas such as south-west New Britain, limestones of Pleistocene and older age dominate the geology. The extent to which these limestone contexts have influenced shell radiocarbon concentrations is not known at this stage.

Dietary factors can also be a significant influence on the composition of shells and consequently also ${ }^{14} \mathrm{C}$ age determinations (Dye 1994; Nunn and Petchey 2013:29; Petchey 2009; Petchey et al. 2012a, 2012b). The species most frequently selected for dating Lapita sites in the Bismarck Archipelago have been members of the Tridacninae subfamily that are suspension/filter feeders through their adult life (Lucas 1988:31). These molluscs fall into Nunn and Petchey's (2013: Table 2) 'high reliability' category as suitable for dating, provided the samples are not from longlived individuals. Four other species used for dating in the archipelago (Conomurex lubuanus, Tectus niloticus, Turbo marmoratus, Anadara antiquata) are in the 'medium reliability' category. Two other taxa, Chama sp. and Spondylus sp., are not discussed by Nunn and Petchey. These sessile molluscs attach themselves to hard substrates (Yonge 1967:78, Table 1), and are suspension/filter 
feeders. This presumably places them in the 'medium/high' to 'medium' reliability categories of Nunn and Petchey, which qualifies them as reasonably suitable for dating. No shell sample is excluded solely for reasons relating to either environmental or dietary conditions.

\section{Issues of association}

There is a common assumption that because a dating sample was recovered from the same sediment matrix as culturally modified items, they must be isochronous. This is not necessarily so. Sandy beaches, the most common contexts for Lapita pottery sites, are notorious for perturbation by animal and natural agencies such as land crabs, pigs, humans, tsunamis, storm surges and tree-falls. Each of these can displace and mix cultural and non-cultural materials of different ages, so dating only one or two samples for a site can give misleading or incorrect results. Lilley (1986: Appendix 1, 505) dated three shells from present-day beaches on Umboi and Tuam Islands between New Guinea and New Britain to assess the possible presence of old shells on modern beaches. One shell from each island returned a Modern age (ANU-3802, ANU-3805). In contrast, a third shell, from Tuam gave a CRA of 690 \pm 70 BP (ANU-3880) (Lilley 1986: Appendix 1, Table 1). Using the Region $2 \Delta \mathrm{R}$ value, this calibrates to $490-55 \mathrm{cal}$. BP. Similarly, for the FAQ site on Garua Island, New Britain, Torrence (unpublished data) dated three surface shells, one of which (Beta-63618: 550 \pm 60 , Tridacna sp.) gave a result of 240-70 cal. BP using the Kimbe Bay $\Delta \mathrm{R}$ value of $45 \pm 19$ years. Finally, six surface shells of Anadara antiquata on a Lizard Island midden in Queensland calibrate to c. 500-600 years before present using a locally calculated $\Delta \mathrm{R}$ offset (Aird 2014: Table 3). Clearly, the inclusion in a dating sample of old shells that were not contemporary with the archaeological context within which they were found can lead to misleading interpretations and may explain some anomalous dating results (cf. Dye 1994). This possibility of 'old shell' (cf. Rick et al. 2005) has obvious implications for the calculation of $\Delta \mathrm{R}$ values from paired archaeological plant/shell samples (cf. Petchey 2009; Petchey et al. 2008). These calculations usually rely on only one or two pairs of samples, when ideally multiple pairs should be used to eliminate the possibility of calculating an inaccurate $\Delta \mathrm{R}$ value. The assumption that the paired materials selected for dating were deposited at more or less the same time has only been addressed at the SZ-8 site in Solomon Islands, where charcoal adhering to the interior of a shell suggests that the death of the mollusc and the combustion event were near-contemporary events (Sheppard et al. 2015:30 and Table 1).

\section{Redating Makekur}

The Makekur Lapita pottery site (FOH) on Adwe Island is one of six Lapita sites in the Arawe Islands of south-west New Britain (Figure 9.3). Three seasons of excavation (1989-91) revealed rich assemblages of pottery, plant remains and other cultural materials (Gosden and Webb 1994; Matthews and Gosden 1997; Summerhayes 2000). The basic stratigraphy comprises three main stratigraphic units (SU), with the Lapita-era materials coming from SU3, the lowest, waterlogged part of the site. This consists of unconsolidated calcareous sand and reef detritus resting on a limestone platform, and locally contained dense wood and other plant remains as well as Lapita pottery and other artefacts (Figure 9.4). Pottery from the D-E-F trench (a group of nine excavation squares) has been assigned to an early stage of the development of Lapita pottery termed Early Lapita (Summerhayes 2000, 2001a, 2001b). Partly on the basis of stylistic comparisons between the pottery of Makekur and other sites, and partly on consideration of the dates then available for Makekur, Summerhayes (2007:145, 2010:12) proposed that the Lapita occupation there began around 3300 years ago. The oldest dates for Makekur, however, are younger than this (Summerhayes 2001a:32, Table 3), and younger than those for the Mussau and Anir sites (Summerhayes 2010: Table 2), with which the Makekur pottery shares many similarities. To examine this apparent discrepancy, a redating program for Makekur was undertaken in 2015. 


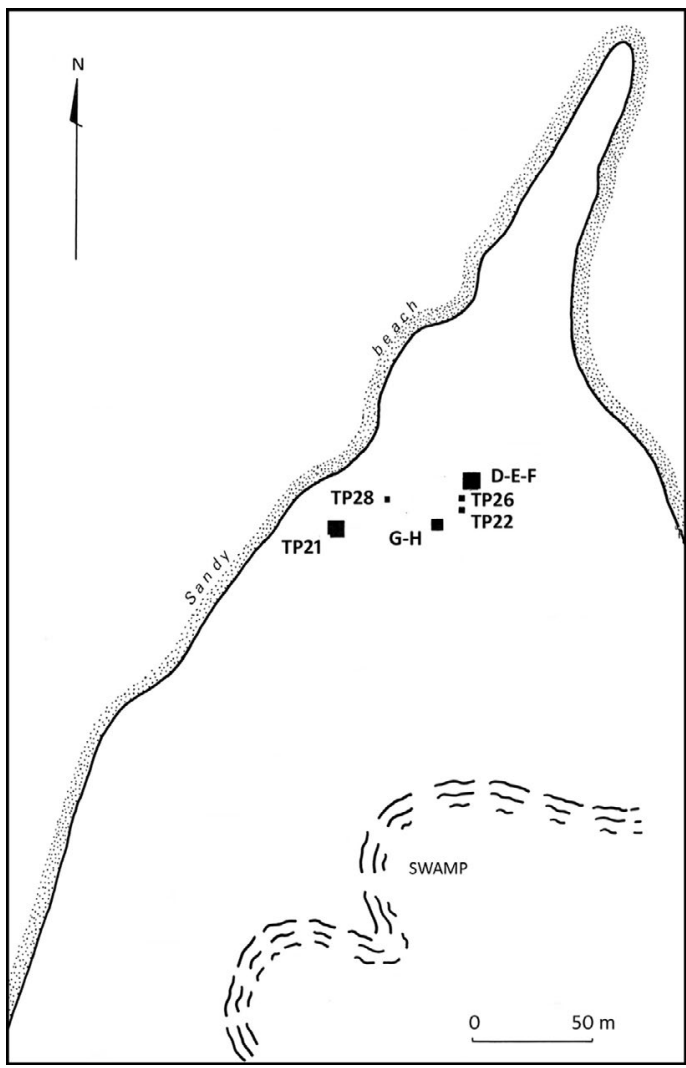

Figure 9.3. Plan of main dated excavation squares at Makekur on Adwe Island, Arawe Islands, West New Britain Province, Papua New Guinea.

Source: Based on original drawing by C. Gosden.

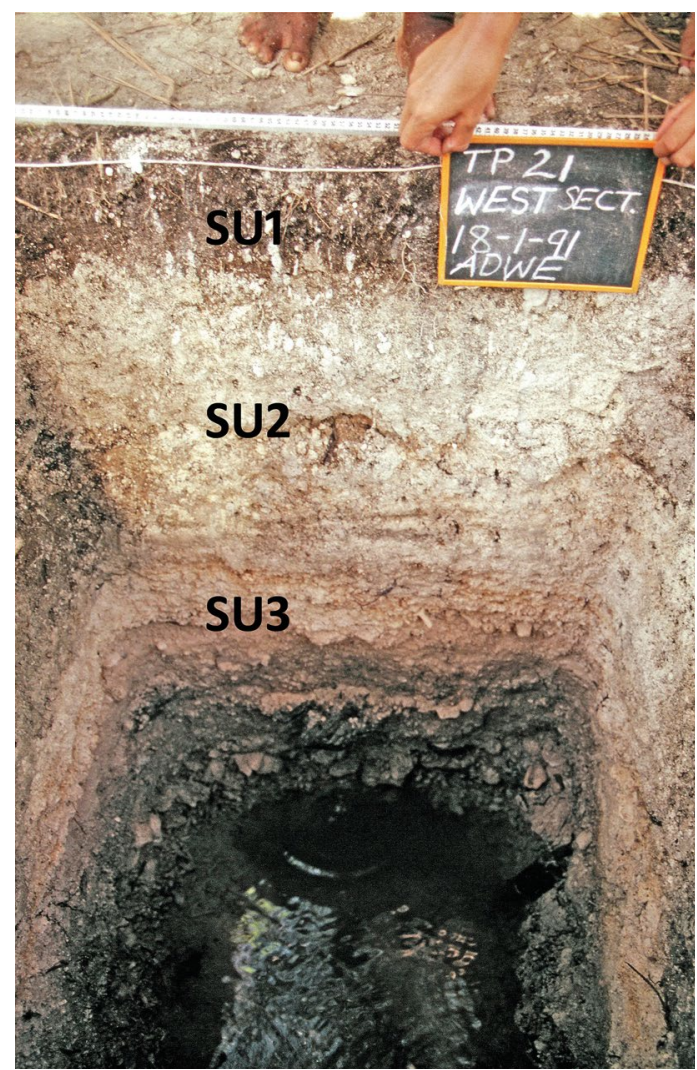

Figure 9.4. Profile of the west face of the original TP21 before extension to $9 \mathrm{~m}^{2}$, showing the four main stratigraphic units.

The basal SU3 is heavily stained dark grey to black by the large quantity of organic material preserved in the anaerobic waterlogged conditions.

Source: C. Gosden.

Prior to the redating program there were 14 dates for Makekur: 10 on plant materials and four on marine shells (Gosden and Webb 1994; Lentfer et al. 2013; Specht and Gosden 1997: Appendix 1; Summerhayes 2001a: Table 3). These are listed on Table 9.2. Four plant results are not relevant here: Wk-8539 lies outside the oldest likely limit for Lapita pottery, and Beta-27943, Wk-8540 and ANU-11192 were from Post-Lapita contexts (Summerhayes 2001a:32-33, Table 3). The remaining six plant dates relate to the Lapita pottery occupation.

For the redating program, six samples of plant origin were selected from the lowest excavation units (XU) of SU4 in six excavation squares, including three previously dated squares. Two samples were of wood and four of short-lived ( $<1$-year growth) Canarium sp. endocarps previously identified by Peter Matthews (cf. Matthews and Gosden 1997) and L. Hayes (1992). Both wood samples had been examined in 1993 by Dr Jill Thompson (Bradford University, UK), after which they were stored in glass phials in distilled water. The wood sample from square G1/XU11 was found embedded vertically in SU4 and is described in the excavation notes as a 'stake'. It is about $200 \mathrm{~mm}$ long, and tapers from 55 by $40 \mathrm{~mm}$ at the top to 5 by $20 \mathrm{~mm}$ at the base. The second wood sample, from TP21/XU17, was taken from a sample of a pole-like item that was too large to remove in its entirety from the field. The pole was found lying horizontally between four upright pieces interpreted as stumps of house posts, though the retained sample of pole does not 
display obvious signs of working or use. Its narrow diameter $(c .40 \mathrm{~mm})$ suggests no significant in-built age. The samples for dating were cut from the surface of each piece of wood and were about $10 \mathrm{~mm}$ long and 5-8 $\mathrm{mm}$ thick.

The wood samples were identified by Carol Lentfer using low- and high-powered light microscopy, and by photomicrographs of transverse, radial and tangential sections generated with the Australian Museum's Zeiss Evo LS 15 scanning electron microscope with a Robinson Backscatter Detector. Comparative reference materials included 14 modern reference samples from trees likely to have been growing on the island or nearby, supplemented by wood identification catalogues across a range of possible taxa (Hope 1998; InsideWood 2004; Oteng-Amoako 1990, 1992; Wheeler 2011). The wood samples are poorly preserved, and are assigned provisionally to cf. Terminalia catappa L., a common strand tree in New Britain. Although the identification is tentative, it is consistent with the recovery of Terminalia sp. endocarps in the lower levels of square G1 (Matthews and Gosden 1997: Table 1).

Before submission for dating, all samples were washed in dilute hydrochloric acid (c. 5 per cent) for 15-20 minutes and rinsed thoroughly in distilled water. They were then oven-dried at $45^{\circ} \mathrm{C}$ for one hour and left overnight to finish drying. The samples were processed at the Australian Nuclear Science and Technology Organisation (ANSTO), Lucas Heights, NSW, Australia, where $\alpha$-cellulose was extracted as described in Hua et al. (2004). The purified $\alpha$-cellulose was then combusted to $\mathrm{CO}_{2}$ and reduced to graphite for ${ }^{14} \mathrm{C}$ analyses using the STAR AMS facility at ANSTO (Fink et al. 2004; Hua et al. 2001).

Table 9.2. Radiocarbon dates run prior to 2015 for the Makekur (FOH) site. Arawe Islands, Papua New Guinea.

\begin{tabular}{|c|c|c|c|c|c|c|c|c|}
\hline Lab code & Context & Material & $\delta^{13} C(\% 0)$ & 14C age & Cal. BP 68.2\% & Prob. & Cal. BP 95.4\% & Prob. \\
\hline \multicolumn{9}{|c|}{ Plant-derived samples } \\
\hline \multirow[t]{4}{*}{ Beta-27942 } & FOH/TP2/XU7 & charcoal & $-25.0 \%(A)$ & $310 \pm 80$ & 467-299 & $68.2 \%$ & $514-20$ & $95.4 \%$ \\
\hline & & & & & & & $514-267$ & $84.8 \%$ \\
\hline & & & & & & & $215-144$ & $8.1 \%$ \\
\hline & & & & & & & 20 & $2.5 \%$ \\
\hline ANU-11192 & $\mathrm{FOH} / \mathrm{D} 3 / \mathrm{XU} 3$ & charcoal & $n / a$ & $1350 \pm 160$ & $1404-1070$ & $68.2 \%$ & 1569-932 & $95.4 \%$ \\
\hline \multirow[t]{4}{*}{ ANU-11187 } & $\mathrm{FOH} / \mathrm{D} 3 / \mathrm{XU9}$ & charcoal & $n / a$ & $2730 \pm 100$ & $2945-2753$ & $68.2 \%$ & $3160-2542$ & $95.4 \%$ \\
\hline & & & & & & & $3160-2701$ & $94.4 \%$ \\
\hline & & & & & & & $2631-2618$ & $0.4 \%$ \\
\hline & & & & & & & $2561-2542$ & $0.6 \%$ \\
\hline \multirow[t]{3}{*}{ Wk-8540 } & $\mathrm{FOH} / \mathrm{E} 2 / \mathrm{XU} 4$ & charcoal & n/a & $2060 \pm 60$ & 2113-1968 & $68.2 \%$ & $2295-1882$ & $95.4 \%$ \\
\hline & & & & & 2113-1968 & $63.1 \%$ & $2295-2270$ & $2.0 \%$ \\
\hline & & & & & 1963-1950 & $5.1 \%$ & $2155-1882$ & $93.4 \%$ \\
\hline ANU-11186 & $\mathrm{FOH} / \mathrm{E} 2 / \mathrm{XU9}$ & charcoal & $n / a$ & $2800 \pm 110$ & $3056-2781$ & $68.2 \%$ & $3219-2741$ & $95.4 \%$ \\
\hline Wk-8539 & $\mathrm{FOH} / \mathrm{F} 1 / \mathrm{XU} 9$ & charcoal & $n / a$ & $3740 \pm 60$ & $4222-3985$ & $68.2 \%$ & $4288-3909$ & $95.4 \%$ \\
\hline \multirow[t]{5}{*}{ Beta-54164 } & $\mathrm{FOH} / \mathrm{G} 2 / \mathrm{XU13}$ & charcoal & $-29.0 \%(M)$ & $2640 \pm 90$ & $2874-2541$ & $68.2 \%$ & $2961-2460$ & $95.4 \%$ \\
\hline & & & & & $2874-2700$ & $60.4 \%$ & & \\
\hline & & & & & $2632-2617$ & $2.6 \%$ & & \\
\hline & & & & & $2585-2575$ & $1.5 \%$ & & \\
\hline & & & & & $2563-2541$ & $3.8 \%$ & & \\
\hline Beta-54165 & $\mathrm{FOH} / \mathrm{TP} 21 \mathrm{~B} / \mathrm{XU13}$ & charcoal & $-28.6 \%(M)$ & $2850 \pm 80$ & $3074-2859$ & $68.2 \%$ & $3180-2781$ & $95.4 \%$ \\
\hline \multirow[t]{3}{*}{ Beta-54166 } & FOH/TP21B/XU17 & charcoal & $-26.9 \%(M)$ & $2730 \pm 70$ & $2917-2760$ & $68.2 \%$ & 2993-2744 & $95.4 \%$ \\
\hline & & & & & 2917-2913 & $1.4 \%$ & & \\
\hline & & & & & $2880-2760$ & $66.8 \%$ & & \\
\hline Wk-32734 & FOH/TP21H/XU14 & $\begin{array}{l}\text { Canarium sp. } \\
\text { endocarp }\end{array}$ & $-26.8 \%(M)$ & $2730 \pm 32$ & $2850-2785$ & $68.2 \%$ & $2916-2760$ & $95.4 \%$ \\
\hline
\end{tabular}




\begin{tabular}{|l|l|l|l|l|l|l|l|l|l|}
\hline Lab code & Context & Material & $\delta^{13}$ C $(\% 0)$ & 14 age & Cal. BP 68.2\% & Prob. & Cal. BP 95.4\% & Prob. \\
\hline Marine samples \\
\hline Beta-27946 & FOH/TP1/XU11 & '0yster' shell & $0 \% 0(\mathrm{~A})$ & $3200 \pm 70$ & $2936-2370$ & $68.2 \%$ & $3245-2111$ & $95.4 \%$ \\
\hline Beta-37561 & FOH/G1/XU6 & $\begin{array}{l}\text { Tridacna Sp. } \\
\text { shell }\end{array}$ & $0.2 \% 0(\mathrm{M})$ & $2860 \pm 70$ & $2570-1992$ & $68.2 \%$ & $2786-1707$ & $95.4 \%$ \\
\hline Beta-54215 & FOH/E2/base & coral & $-1.2 \% 0(\mathrm{M})$ & $4290 \pm 60$ & $4351-3756$ & $68.2 \%$ & $4631-3446$ & $95.4 \%$ \\
\hline Beta-55323 & FOH/D1/XU10 & $\begin{array}{l}\text { unidentified } \\
\text { shell }\end{array}$ & $0 \% 0(\mathrm{~A})$ & $3230 \pm 70$ & $2990-2412$ & $68.2 \%$ & $3291-2148$ & $95.4 \%$ \\
\hline Beta-55456 & FOH/TP28/XU14 & $\begin{array}{l}\text { Tridacna Sp. } \\
\text { shell }\end{array}$ & $2.4 \% 0(\mathrm{M})$ & $2840 \pm 60$ & $2535-1961$ & $68.2 \%$ & $2760-1697$ & $95.4 \%$ \\
\hline
\end{tabular}

The dates are calibrated with 0xCal 4.2.4 using the Intcal13 and Marine13 curves (Bronk Ramsey 2009; Reimer et al. 2013). Shell dates are calibrated using the Region 2 value of $\Delta R=273 \pm 216$ years (Petchey and Ulm 2012: Figure 1, 55), assuming 100 per cent marine contribution of radiocarbon. For the $\delta^{13} \mathrm{C}$ values, $A=$ Assumed, $M=$ Measured.

Source: Authors' summary.

\section{Results}

\section{Redating Makekur}

Table 9.3 shows the six AMS results for Makekur. Samples OZS476 (Canarium endocarp from G2/XU15) and OZS477 (cf. T. catappa wood from TP21/XU17) are statistically identical and bracket the range 3000-2880 cal. BP $\left(T=1.560976, \chi^{2}(1: 0.05)=3.84\right)$. Three results (OZS475: cf. T. catappa wood from G1/XU11; OZS474: Canarium endocarp from F3/XU18; OZS478: Canarium endocarp from TP22/XU18) are also statistically identical and bracket the range $2750-2500 \mathrm{cal}$. BP $\left(\mathrm{T}=2.906667 ; \chi^{2}(2: 0.05)=5.99\right)$. At $2850-2760 \mathrm{cal}$. BP, the sixth sample (OZS479: Canarium sp. endocarp from TP26/XU17) sits between these two groups.

With the exception of the three youngest dates, the other results are generally comparable with those obtained previously. There are now four dated samples from TP21 (OZS477, Beta-54165, Beta-54166 and Wk-32734). OZS477 is the same as the two Beta Analytic results but differs significantly from Wk-32734 $\left(T=4.912068, \chi^{2}(1: 0.05)=3.84\right)$. This difference arguably may be due to the small standard errors of OZS477 and Wk-32734 compared to those of the two Beta Analytic dates.

Table 9.3. New AMS dates on terrestrial plant materials for Makekur (FOH), calibrated with 0xCal 4.2.4 using the Intcal13 curve (Bronk Ramsey 2009; Reimer et al. 2013).

\begin{tabular}{|c|c|c|c|c|c|c|c|c|}
\hline \multirow[b]{2}{*}{ Lab code } & \multicolumn{8}{|c|}{ Makekur dates - ANSTO 2015 - 0xCal 4.2.4 } \\
\hline & Context & Material & $\delta^{13} \mathrm{C}$ & ${ }^{14} \mathrm{C}$ age & $\begin{array}{l}\text { Cal. BP } \\
68.2 \%\end{array}$ & Prob. & $\begin{array}{l}\text { Cal. BP } \\
95.4 \%\end{array}$ & Prob. \\
\hline \multirow[t]{3}{*}{$0 Z S 476$} & $\mathrm{FOH} / \mathrm{G} 2 / \mathrm{XU15}$ & Canarium sp. endocarp & $-25.9 \pm 0.1 \% 0$ & $2860 \pm 20$ & $3004-2929$ & $68.2 \%$ & $3060-2890$ & $95.4 \%$ \\
\hline & & & & & & & $3060-2922$ & $91.0 \%$ \\
\hline & & & & & & & $2906-2890$ & $4.4 \%$ \\
\hline OZS477 & $\mathrm{FOH} / \mathrm{TP} 21 / \mathrm{XU17}$ & $\begin{array}{l}\text { cf. Terminalia catappa } \\
\text { wood }\end{array}$ & $-25.9 \pm 0.1 \%$ & $2820 \pm 25$ & $2954-2880$ & $68.2 \%$ & 2991-2859 & $95.4 \%$ \\
\hline \multirow[t]{3}{*}{$0 Z S 479$} & FOH/TP26/XU17 & Canarium sp. endocarp & $-27.2 \pm 0.1 \% 0$ & $2690 \pm 25$ & 2841-2757 & $68.2 \%$ & $2846-2755$ & $95.4 \%$ \\
\hline & & & & & $2841-2827$ & $11.9 \%$ & & \\
\hline & & & & & $2795-2757$ & $56.3 \%$ & & \\
\hline
\end{tabular}




\begin{tabular}{|c|c|c|c|c|c|c|c|c|}
\hline & Makekur dates - & ANSTO 2015 - OxCal 4.2 & & & & & & \\
\hline Lab code & Context & Material & $\delta^{13} \mathrm{C}$ & ${ }^{14}$ C age & $\begin{array}{l}\text { Cal. BP } \\
68.2 \%\end{array}$ & Prob. & $\begin{array}{l}\text { Cal. BP } \\
95.4 \%\end{array}$ & Prob. \\
\hline $0 Z 5475$ & $\mathrm{FOH} / \mathrm{G} 1 / \mathrm{XU11}$ & $\begin{array}{l}\text { cf. Terminalia catappa } \\
\text { wood }\end{array}$ & $-28.6 \pm 0.1 \% 0$ & $2560 \pm 25$ & $2747-2685$ & $68.2 \%$ & $2754-2518$ & $95.4 \%$ \\
\hline & & & & & & & $2754-2609$ & $78.8 \%$ \\
\hline & & & & & & & $2633-2616$ & $5.5 \%$ \\
\hline & & & & & & & $2588-2538$ & $10.0 \%$ \\
\hline & & & & & & & $2527-2518$ & $1.0 \%$ \\
\hline $0 Z 5474$ & FOH/F3/XU18 & Canarium sp. endocarp & $-25.5 \pm 0.1 \% 0$ & $2525 \pm 25$ & $2737-2539$ & $68.2 \%$ & $2743-2496$ & $95.4 \%$ \\
\hline & & & & & $2737-2699$ & $28.7 \%$ & & \\
\hline & & & & & $2632-2617$ & $11.1 \%$ & & \\
\hline & & & & & $2587-2539$ & $28.5 \%$ & & \\
\hline $0 Z 5478$ & F0H/TP22/XU18 & Canarium sp. endocarp & $-24.7 \pm 0.1 \% 0$ & $2500 \pm 25$ & $2715-2503$ & $68.2 \%$ & 2726-2489 & $95.4 \%$ \\
\hline & & & & & $2715-2695$ & $10.2 \%$ & $2726-2650$ & $23.6 \%$ \\
\hline & & & & & $2635-2615$ & $10.8 \%$ & $2645-2489$ & $71.8 \%$ \\
\hline & & & & & $2592-2503$ & $47.2 \%$ & & \\
\hline
\end{tabular}

Source: Authors' summary.

Summerhayes' (2000) analysis of pottery from Makekur focused on trenches D-E-F and G-H that now have four dates each. For the G-H trench, Summerhayes (2000:91) analysed the sherds from squares G1 and G2, each of which has two dates. When calibrated, OZS475 (cf. Terminalia wood) from G1/XU11 is older than shell date Beta-37561 from G1/XU6, consistent with their stratigraphic relationship. Beta-54164 (charcoal) from G2/XU13 and OZS476 (Canarium endocarp) from G2/XU15 are also stratigraphically consistent.

For trench D-E-F, three dates from D1/XU10 (Beta-55323, shell), D3/XU9 (ANU-11187, charcoal) and E2/9 (ANU-11186, charcoal) are statistically the same, as would be expected as they came from similar depths $\left(T=4.067498, \chi^{2}(2: 0.05)=5.99\right)$. The fourth sample (OZS474, Canarium endocarp) from F3/XU18 overlaps with only one of these, and is later than the other two, despite being from a comparable depth. This discrepancy might be explained by the OZS474 sample being introduced into XU18 from a higher level when one side of square F3 collapsed during excavation of XU16-XU18.

The three youngest dates (OZS474, OZS475 and OZS478) are later than expected, though the reason for this is not clear. The samples might have been contaminated during selection and preparation, though this seems unlikely as all samples were prepared for submission to ANSTO at the same time and in the same manner. Furthermore, the three youngest dates are consistent with

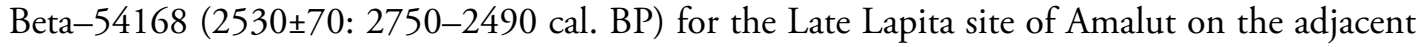
New Britain mainland (Specht and Gosden 1997: Appendix 1). The late results at Makekur could indicate that site use continued into Late Lapita times, during which there was downward movement of dating materials. This possibility receives support from the pottery analysis of trench D-E-F, which divided the basal deposit ( $40-45 \mathrm{~cm}$ thick) into four analytical units, A to D from base upwards (Summerhayes 2000:22). Conjoining of sherds revealed that parts of the same vessels were recovered across two, three and four analytical units, clearly indicating vertical movement (Summerhayes 2000: Table 3.1). Whatever the reason for the younger dates, they are not relevant to the rest of the discussion. 
The results from the four dating laboratories (Beta Analytic, Waikato, ANU and ANSTO) over 30 years are broadly consistent and suggest that the pottery occupation is unlikely to have begun at Makekur before c. $3100 \mathrm{cal}$. BP, the oldest end of the date ranges. This is at the youngest end of the date range of 3480-3150 cal. BP for the W-K2 eruption, and of 3330-3040 cal. BP and 3360-3040 cal. BP for the reoccupation of the Willaumez Peninsula and Garua Island respectively, both ranges at 95.4 per cent probability (Petrie and Torrence 2008: Tables 5 and 6). This would place the start of Makekur's Lapita pottery occupation around the time of the southerly dispersal into Remote Oceania. If so, this would conflict with the stylistic analysis of the Makekur pottery, as Summerhayes (2001a:35, Figure 4) assigned the D-E-F sherds to his Early stage of Lapita pottery, and those from $\mathrm{G}-\mathrm{H}$ to his Middle stage. But OZS476 for G2/XU15 is statistically the same as the oldest date for D-E-F, ANU-11186 for E2/XU9. Furthermore, in the Mussau and Anir Islands, the Early Lapita stage is dated around the upper limits of 3450 and 3300 cal. BP (Denham et al. 2012; Kirch 2001; Summerhayes 2007, 2010). To examine this issue further, we now turn to dates for the broader archipelago region.

\section{The Bismarck Archipelago}

Only 38 dates from 14 sites (plant: 25 dates, 9 sites; shell: 13 dates, 6 sites) survived the culling process, with only ECA having both plant and shell samples (Tables 9.4 and 9.5). Table 9.4 includes several plant dates from Lapita pottery contexts used by Petrie and Torrence (2008) for calculating the dates of the W-K2 event and subsequent reoccupation (cf. Denham et al. 2012:44). Over half of the samples (20) are from sites in the Mussau Islands, and 16 of these are from the ECA site. The latter are arranged on Tables 9.4 and 9.5 according to the spatial and vertical divisions discussed by Kirch (2001: Chapter 10, Appendix 10.1):

- Airfield transect: 1 plant, 0 shell;

- W200 transect: 1 plant, 0 shell;

- Area A: 1 plant, 2 shell;

- Area B: 3 plant, 0 shell;

- W250 transect: 2 plant, 4 shell;

- Area C: 2 plant, 0 shell.

Although Area C belongs to a late stage of the pottery occupation (Kirch 2001: Chapter 10), two plant dates from this area are included as they fall within the time range of the basal Zone C3 at Area B.

Two samples dating pre-pottery levels are included: Beta-26261 (3158-2951 cal. BP) from Kautaga Island (FPA) in the Kove Islands, and Wk-7558 (3254-3053 cal. BP) from Melele cave (ERD) on Babase Island in the Anir group (Lilley 1991:316, Table 1; Summerhayes 2001a:34, Table 3). These place the start of pottery at these sites well within the range discussed above for the initial occupation of Makekur. This, however, is in marked contrast to other dates with claimed pottery associations that precede these sites by several hundred years. 


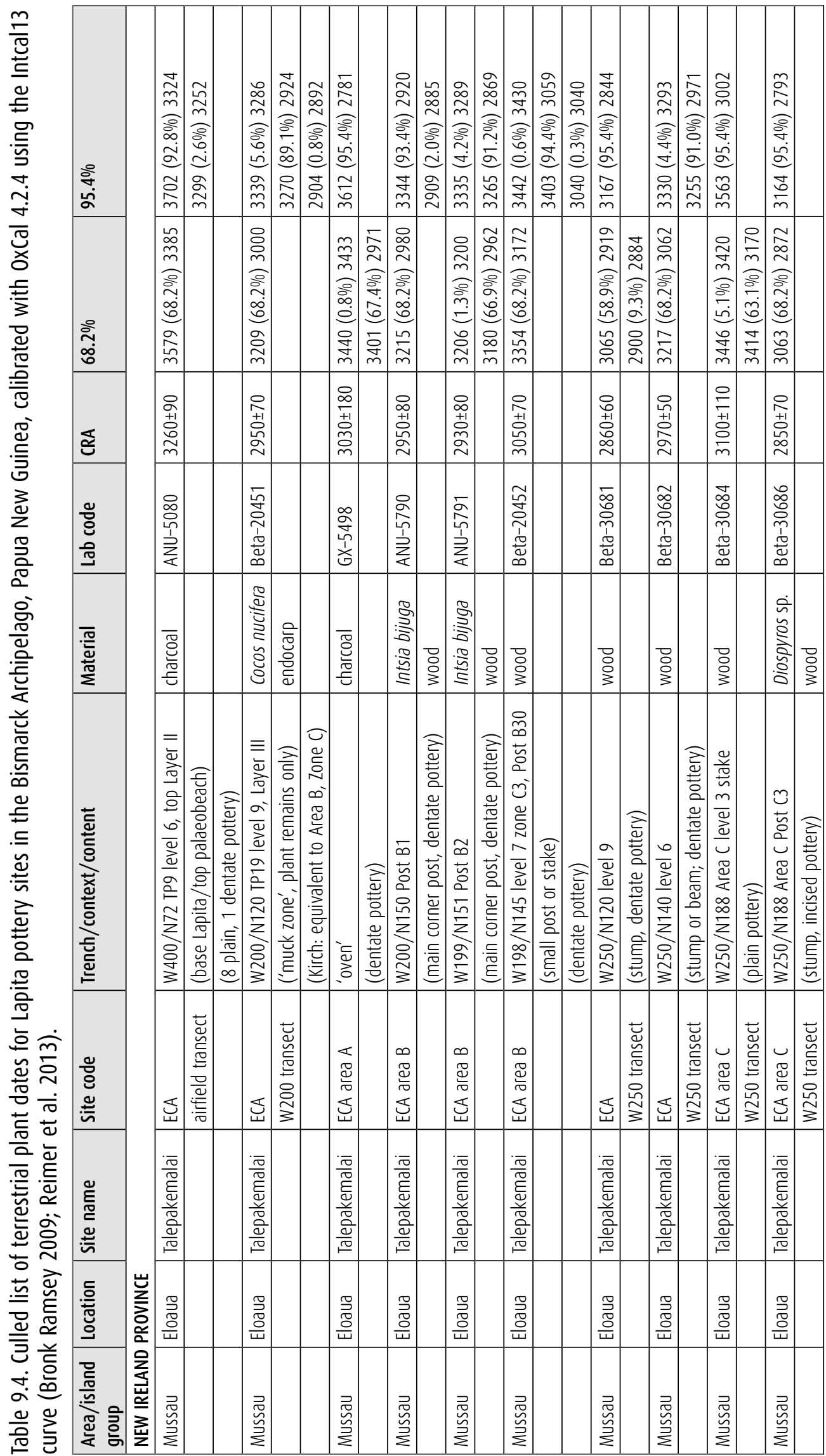




\begin{tabular}{|c|c|c|c|c|c|c|c|c|c|c|c|c|c|c|c|c|c|c|c|c|}
\hline 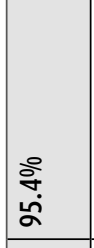 & 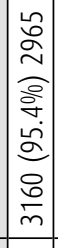 & & & 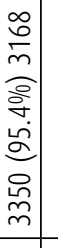 & & 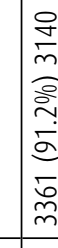 & 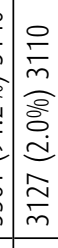 & 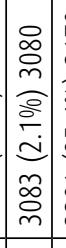 & 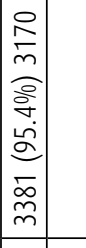 & 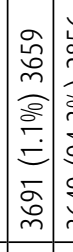 & & 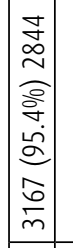 & & 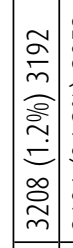 & 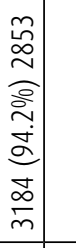 & & 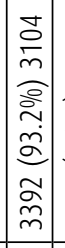 & 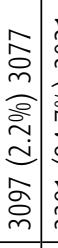 & 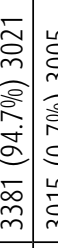 & \\
\hline 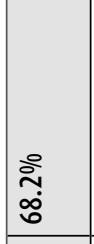 & 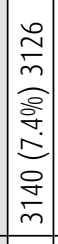 & 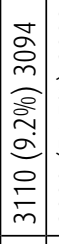 & 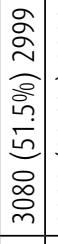 & 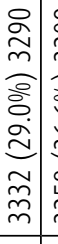 & 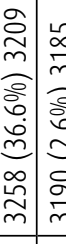 & 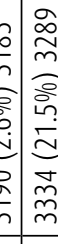 & 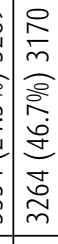 & & 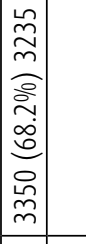 & 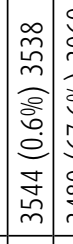 & 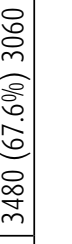 & 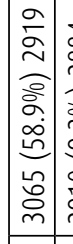 & 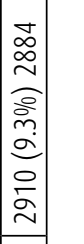 & 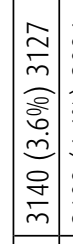 & 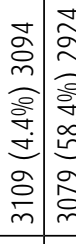 & 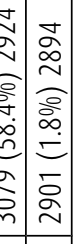 & 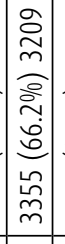 & 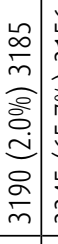 & 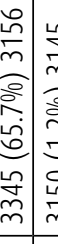 & 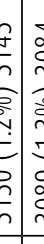 \\
\hline ฐ્త & $\begin{array}{l}\bar{n} \\
\stackrel{+}{+} \\
\tilde{a} \\
\tilde{N}\end{array}$ & & & 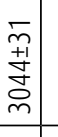 & & 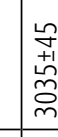 & & & 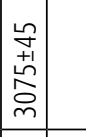 & 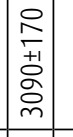 & & $\begin{array}{r}0 \\
0 \\
+1 \\
0 \\
0 \\
\sim\end{array}$ & & \begin{tabular}{|c|c}
0 \\
0 \\
+1 \\
$\infty$ \\
$\infty$ \\
$\sim$ \\
\end{tabular} & & & $\begin{array}{l}0 \\
0 \\
+1 \\
0 \\
0 \\
m\end{array}$ & & 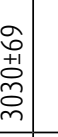 & \\
\hline 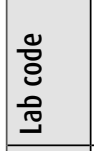 & 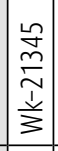 & & & 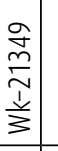 & & 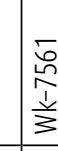 & & & 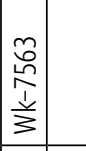 & 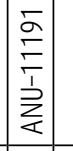 & & $\begin{array}{c}2 \\
\frac{2}{1} \\
\frac{1}{3} \\
\end{array}$ & & $\mid$\begin{tabular}{|c}
$\tilde{n}$ \\
$\hat{n}$ \\
$\hat{z}$ \\
$z$
\end{tabular} & & & 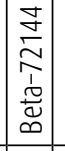 & & $\begin{array}{c}\frac{d}{c} \\
\frac{n}{n} \\
\frac{1}{z} \\
\end{array}$ & \\
\hline 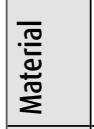 & 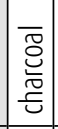 & & & 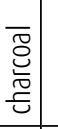 & & \begin{tabular}{|l}
$\overline{\widetilde{S}}$ \\
읃 \\
\end{tabular} & & & 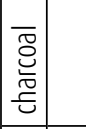 & 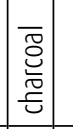 & & $\mid$ & 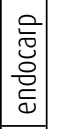 & 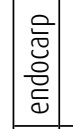 & & & 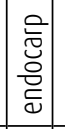 & & 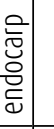 & \\
\hline 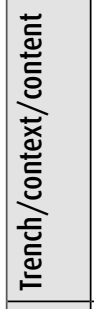 & 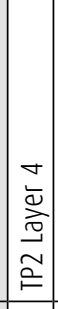 & 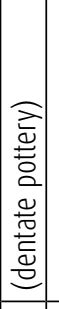 & & 它 & 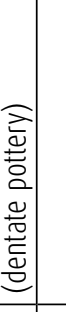 & $\begin{array}{l}0 \\
: \overline{\bar{n}} \\
\bar{n} \\
\bar{E}\end{array}$ & 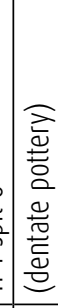 & & 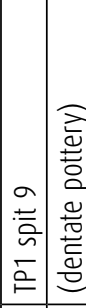 & 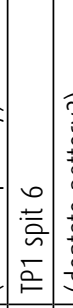 & 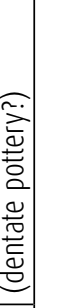 & 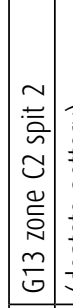 & 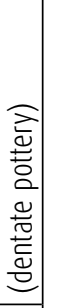 & 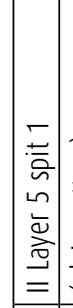 & 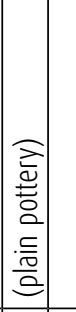 & & 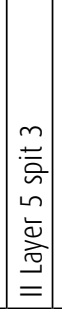 & 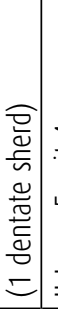 & 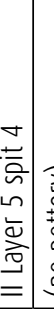 & \\
\hline 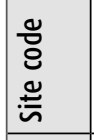 & $\tilde{\tilde{u}}$ & & & 约 & & $\underset{\Psi}{\Xi}$ & & & 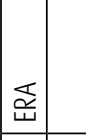 & $\underset{\Psi}{\stackrel{ }{\Psi}}$ & & 芯 & & $\approx$ & & & $\approx$ & & $\approx$ & \\
\hline 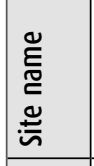 & 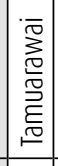 & & & 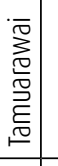 & & $\begin{array}{l}\vec{\sigma} \\
\stackrel{\vec{E}}{\bar{\sigma}} \\
\end{array}$ & & & 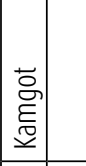 & 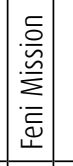 & بّ & $\mid \begin{array}{l}\overline{\frac{D}{z}} \\
\frac{\bar{z}}{\tilde{a}}\end{array}$ & بु & 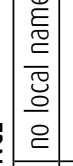 & & & 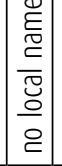 & & 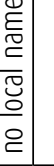 & \\
\hline . 들 & 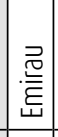 & & & 密 & & $\begin{array}{l}\tilde{\tilde{N}} \\
\text { 芯 }\end{array}$ & & & 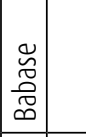 & 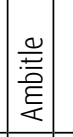 & $\begin{array}{l}5 \\
\text { o } \\
\text { a } \\
\text { za }\end{array}$ & 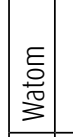 & 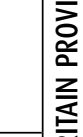 & \begin{tabular}{|l}
0 \\
总 \\
\end{tabular} & & & $\mid \begin{array}{l}0 \\
己 \\
心 \\
心\end{array}$ & & 胥 & \\
\hline 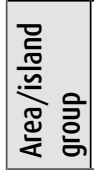 & . & & & 胥 & & 定 & & & 言 & 言 & 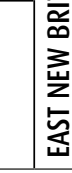 & 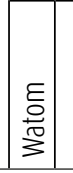 & 誉 & 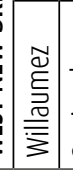 & 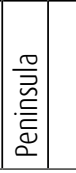 & & 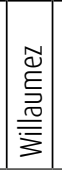 & 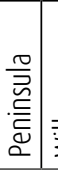 & 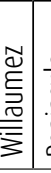 & \\
\hline
\end{tabular}




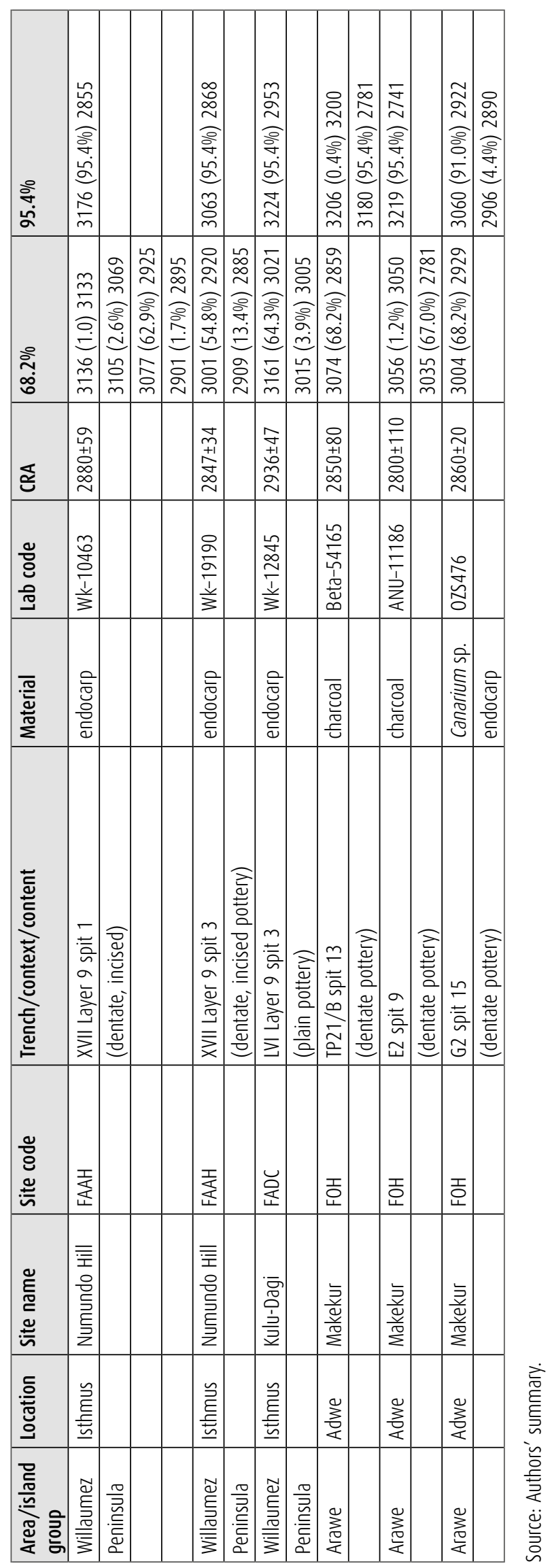


Comparison between Tables 9.4 and 9.5 reveals a marked division between the dates for the Mussau sites and those from the rest of the archipelago. Nine of the 10 shell dates and three of the plant dates for the Mussau sites have ranges that start before 3400 years ago, though the lower end of their ranges, with the exception of Beta-30693, fall within the expected period of the start of Lapita pottery. This contrasts with the rest of the archipelago, where no shell date and only one plant date (ANU-11191) has a range with an upper limit exceeding 3400 years. This raises questions about appropriate $\Delta \mathrm{R}$ values for the Mussau sites, the nature of the samples and their contexts.

Kirch (2001:199-216) acknowledged the problems with calculation of a single $\Delta \mathrm{R}$ value for the Mussau sites and noted that use of the 'model surface ocean' $\Delta \mathrm{R}$ value tends to yield more reasonable results for some dates. Until reliable $\Delta \mathrm{R}$ values become available, it may be advisable to set aside all shell dates for the Mussau sites and those on the south coast of New Britain. These $\Delta \mathrm{R}$ issues cannot be resolved here, but it is worthwhile to consider other potential reasons for the old results for both shell and plant samples.

The dating of the Lapita occupation on the palaeobeach of A at ECA has been the subject of discussion over the last 30 years (e.g. Kirch 1987, 2001:205; Summerhayes 2010:22-23), but without resolution, because of the lack of plant materials for dating and the issues surrounding the appropriate $\Delta \mathrm{R}$ value for shell samples. Three shell dates on Table 9.5 relate to the palaeobeach (Beta-30677, Beta-30678, Beta-30679), plus Beta-30680, which was excluded because the sample was probably an old shell from a Pre-Lapita context (Kirch 2001:228). The three retained dates are all older than those for FPA and Melele cave, and may also derive from a pre-pottery context. A similar explanation may be relevant for Beta-30693 (Hippopus hippopus shell) from the EKE site on Boliu Island in the Mussau group, which gives a calibrated range outside reasonable expectations (Appendix 1). This shell was recovered from Layer II along with calcareous sandtempered plain sherds (Kirch 2001:168-169). Kirch notes that burrowing by land crabs has moved some sand-tempered sherds from Layer II upwards into Layer IC, and further notes the displacement of one sherd downwards into the pre-pottery Layer III. This opens the likelihood that the dated shell sample relates to Layer III and predates the sand-tempered sherds.

ANU-5080 (3579-3385 cal. BP) is the only plant date referring to the ECA palaeobeach and is one of the oldest dates for a Lapita pottery context (Kirch 2001:83). The sample came from Layer II, the top of the palaeobeach, of test pit TP9, about $175 \mathrm{~m}$ west of the W250 transect (Kirch 2001: Figure 4.1). This context contained only nine sherds compared with 205 in the overlying Layer IB, suggesting that the Layer II sherds have been displaced downwards. This raises questions about the relevance of ANU-5080: was it also moved downwards with the sherds, was it from old wood, did the sample have large in-built age, or does it relate to a pre-pottery combustion event? The PNG National Museum excavations of 1978 in Area A of ECA also produced a very old date (GX-5499: 3900 280 , 4810-3975 cal. BP; Bafmatuk et al. 1981:80) for the fill of a pit with Lapita pottery. This date is clearly irrelevant for dating the pottery (Kirch et al. 1987:125; Spriggs 1990:17). The origin of this sample is not known: it could relate to a Pre-Lapita natural combustion event, Pre-Lapita human use of the area for which there is currently no archaeological evidence, or the burning of old wood during the Lapita pottery occupation. It is impossible to resolve this matter with the currently available evidence, and so the dating of the palaeobeach finds remains uncertain.

The only plant date range exceeding 3400 years at its upper limit from beyond the Mussau Islands is ANU-11191 from the Feni Mission site (ERG) in the Anir Islands off southern New Ireland. The calibrated result shows a very low probability that the true age lies in the range $3544-3538 \mathrm{cal}$. BP (0.6 per cent), and more likely to be in the range 3480-3060 cal. BP (67.6 per cent). This sample of unidentified charcoal has the potential for in-built age and has a very large standard error of 170 years that extends the range limits. 


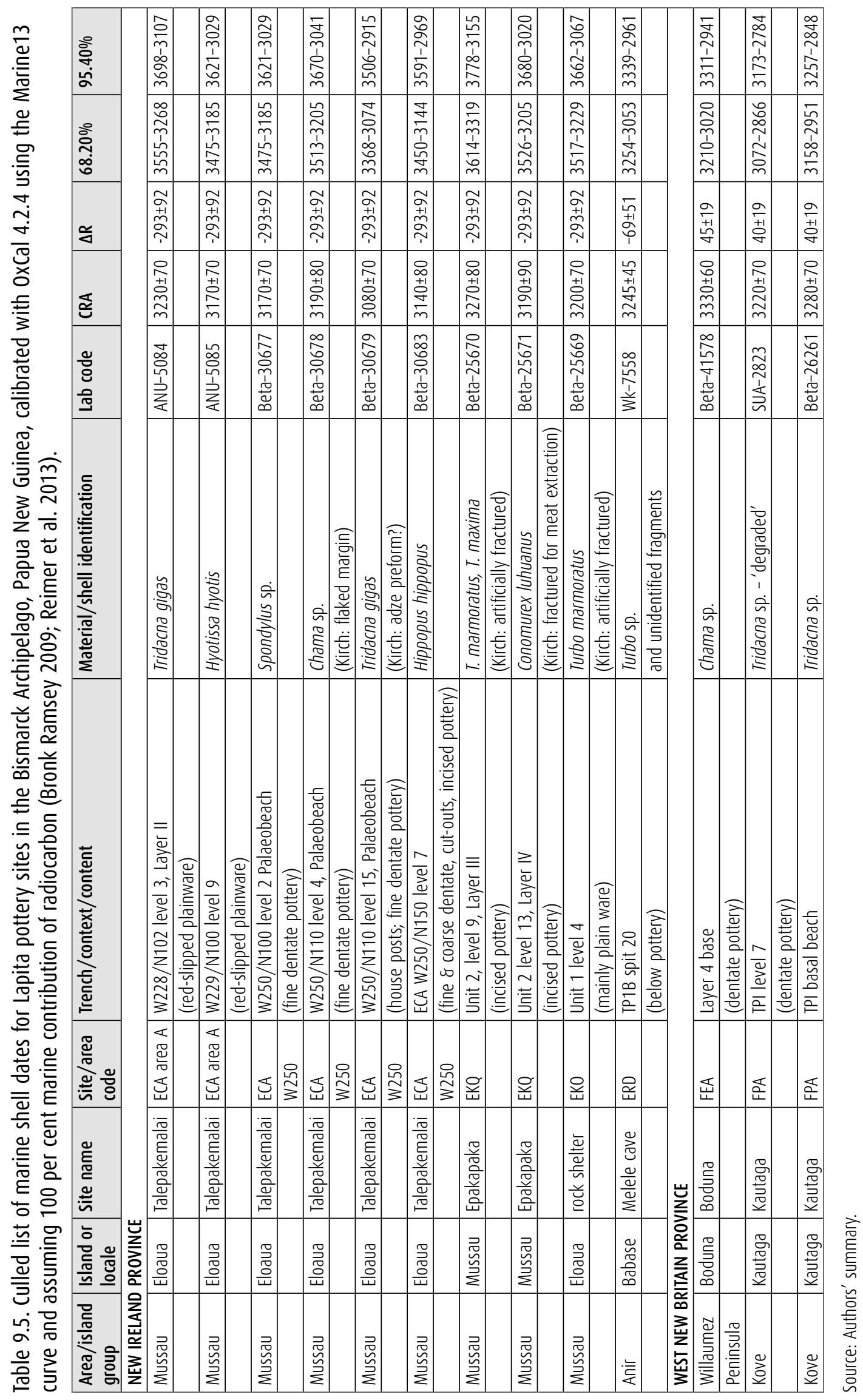


Most of the remaining results for both plant and shell samples fall around or below 3300 years cal. BP at their maximum range limits, with only five plant date ranges exceeding 3300 years. Three of these samples (EQS: Wk-21349; ERA: Wk-7561, Wk-7563) were unidentified charcoal with unknown in-built age, and two (FYS: Beta-72144, NZA-3734) were based on short-lived nut endocarps, unidentified but most likely to be Canarium sp. (Torrence and Stevenson 2000:238, Table 1). The two FYS dates are the oldest plant results for New Britain. Table 9.6 shows the pooled means of the pairs of ERA and FYS dates calculated by Calib 7.0.2. The dates for all three sites fall on a problematic part of the calibration curve, but the probability distributions of the pooled means do not favour strongly an age over 3300 years. Rather, there is almost equal probability that it falls in either 3335-3290 (33.2 per cent) or 3270-3215 (35.0 per cent) cal. BP for ERA, and 3340-3290 (27.9 per cent) or 3270-3210 (34.0 per cent) cal. BP for FYS. These ranges and probability distributions are essentially the same as those for Wk-21349 at EQS, 3330-3290 (29.0 per cent) and 3260-3210 (36.6 per cent) cal. BP.

Table 9.6. Pooled means of dates for five Bismarck Archipelago Lapita sites calibrated with 0xCal 4.2.4 using the IntCal13 curve (Bronk Ramsey 2009; Reimer et al. 2013).

\begin{tabular}{|c|c|c|c|c|c|c|}
\hline Region & Site & Lab code & CRA & Pooled mean & Calibrated mean & Probability \\
\hline \multirow[t]{2}{*}{ Mussau } & \multirow[t]{2}{*}{$E C A / B$} & ANU-5790 & $2950 \pm 80$ & \multirow[t]{2}{*}{$2940 \pm 57$} & \multirow[t]{2}{*}{$3171-3001$} & \multirow[t]{2}{*}{$68.2 \%$} \\
\hline & & ANU-5791 & $2930 \pm 80$ & & & \\
\hline \multirow[t]{2}{*}{ Anir } & \multirow[t]{2}{*}{ ERA } & Wk-7561 & $3035 \pm 45$ & \multirow[t]{2}{*}{$3055 \pm 32$} & $3335-3288$ & $33.2 \%$ \\
\hline & & Wk-7563 & $3075 \pm 45$ & & $3267-3215$ & $35.0 \%$ \\
\hline \multirow[t]{3}{*}{ Garua } & \multirow[t]{3}{*}{ FYS } & Beta-72144 & $3060 \pm 60$ & \multirow[t]{3}{*}{$3047 \pm 45$} & $3340-3286$ & $27.9 \%$ \\
\hline & & NZA-3734 & $3030 \pm 69$ & & $3272-3207$ & $34.0 \%$ \\
\hline & & & & & 3197-3182 & $6.3 \%$ \\
\hline Willaumez & FAAH & Wk-10463 & $2880 \pm 59$ & \multirow[t]{2}{*}{$2855 \pm 29$} & $3005-2923$ & $60.7 \%$ \\
\hline Isthmus & & Wk-19190 & $2847 \pm 34$ & & 2906-2890 & $7.5 \%$ \\
\hline \multirow[t]{3}{*}{ Adwe } & \multirow[t]{3}{*}{$\mathrm{FOH}$} & Beta-54165 & $2850 \pm 80$ & \multirow[t]{3}{*}{$2858 \pm 19$} & 3002-2943 & $65.4 \%$ \\
\hline & & ANU-11186 & $2800 \pm 110$ & & 2935-2930 & $2.8 \%$ \\
\hline & & $0 Z S 476$ & $2860 \pm 20$ & & & \\
\hline
\end{tabular}

The ECA/B dates were on posts from the structure in Area B. Plant samples only.

Source: Authors' summary.

This congruence of results from ERA, EQS and FYS contrasts markedly with the pooled means calculated for the three other Bismarck Archipelago sites, whose pooled means do not exceed 3200 years. The FAAH pottery assemblage (Specht and Torrence 2007b) has not been assigned to a specific stage of Summerhayes' (2001b) developmental scheme for Lapita pottery, but several sherds show close similarities to those of his Early Lapita sites (Specht and Torrence 2007b: Figures 8E, 8F and 11G). The similarity between the pooled means for FOH and FAAH supports this, though the pooled mean for the ECA/B house posts is slightly older. Interestingly, the ECA/B and FAAH results fall within that for Beta-20415 (3210-3000 cal. BP, coconut endocarp) from the 'muck zone' on the W200 transect (Kirch 2001:86, 224), though Beta20451 was associated only with plant remains, and no specific cultural materials. The lack of agreement between the results for ERA, EQS and FYS, and those for ECA/B, Beta-20451 and FAAH remains a matter for further exploration, though the slight preference for the 3270-3210 calibrated range in the ERA, EQS and FYS results brings them closer to the other sites. This would be consistent with the dates for the pre-pottery levels at FPA and Melele cave discussed above, though there is no guarantee that pottery appeared in either site immediately after these dates. The dates do not support its appearance earlier than the upper range limit of Wk-7558, $3250 \mathrm{cal}$. BP. As a working hypothesis, therefore, we suggest that pottery was introduced to the Bismarck Archipelago after c. 3250 cal. BP (Melele cave, upper range limit of Wk-7558), and possibly as late as c. $3150 \mathrm{cal}$. BP (Kautaga Island, upper range limit of Beta-26261). 


\section{Expansion into Remote Oceania}

This revised starting date reduces the length of time between the appearance of pottery in the archipelago and its dispersal into Remote Oceania (cf. Specht et al. 2014). Table 9.7 presents the dates proposed by various authors for initial settlement of several Lapita sites in Remote Oceania based on Bayesian analyses, except for the Atanoasao site in Vanuatu, which is a pooled mean derived through the SHcal13.14C curve (Hogg et al. 2013) of Calib 7.0.2. This curve was used for all other calculations, except for those provided by Sheppard et al., who used the Northern Hemisphere IntCal13 curve.

Table 9.7. Date ranges for first settlement of island groups in Remote 0ceania.

\begin{tabular}{|c|c|c|c|}
\hline Region/site & Start cal. BP & Basis of calculation & Reference \\
\hline \multicolumn{4}{|l|}{ SE SOLOMON IS } \\
\hline Nanggu SZ-8 & $2920-2793$ & Bayesian analysis, 95.4\% & \multirow[t]{2}{*}{ Sheppard et al. 2015:31 } \\
\hline Nenumbo RF-2 & $3185-2785$ & Bayesian analysis, 95.4\% & \\
\hline \multicolumn{4}{|l|}{ VANUATU } \\
\hline \multirow[t]{2}{*}{ Makué } & $3192-2945$ & Bayesian analysis, 68.2\% & Galipaud et al. 2014: 111, Zone 3 only \\
\hline & $3313-3008$ & Bayesian analysis, 95.4\% & Sheppard et al. 2015: 34, all samples \\
\hline Atanoasao & $2954-2854$ & Pooled mean & Pineda and Galipaud 1998:778 \\
\hline Teouma cemetery & $2940-2880$ & Bayesian analysis, $68.2 \%$ & Petchey et al. 2014:240 \\
\hline Teouma midden & $2920-2870$ & Bayesian analysis, $68.2 \%$ & Petchey et al. 2015:104 \\
\hline \multicolumn{4}{|l|}{ FIJI } \\
\hline Bourewa & $2838-2787$ & Bayesian analysis, $68.2 \%$ & Nunn and Petchey 2013:30 \\
\hline Naigani & $3001-2790$ & Bayesian analysis, 95.4\% & Sheppard et al. 2015:32 \\
\hline \multicolumn{4}{|l|}{ TONGA } \\
\hline Nukuleka & $2846-2830$ & Bayesian analysis, 68.2\% & Burley et al. 2015 \\
\hline
\end{tabular}

The Bayesian analyses are those provided by the cited authors using 0xcal (see references for details). All authors used the Southern Hemisphere calibration curve SHCal13 (Hogg et al. 2013) except Sheppard et al. (2015:30), who used the Northern Hemisphere IntCal.13 curve. The pooled mean for Atanoasao in Vanuatu was calculated in Calib 7.0.2, and then calibrated with the SHCal13 curve of OxCal 4.2.4 (Bronk Ramsey 2009; Hogg et al. 2013).

Source: See references in table.

The seemingly anomalous dating of Makué (Sheppard et al. 2015:34) is resolved by the revised calculations offered by Galipaud et al. (2014:111) for the basal Zone 3 at Makué.

Setting aside the Sheppard et al. calculation, all of the proposed date ranges sit comfortably with the revised range for the Bismarck Archipelago presented here. The closeness of the results for the Bismarck Archipelago and Remote Oceania suggest that dispersal into Remote Oceania occurred soon after the appearance of Lapita pottery in the archipelago. This is consistent with comparisons between the Makué pottery and that of ECA, ERA and FOH (Bedford and Galipaud 2010: Figure 7; Galipaud 2010: Figure 2; Noury and Galipaud 2011:23, 30, 65), which imply only a brief interval in the archipelago before southerly dispersal.

\section{Discussion and conclusion}

The new dates for the Makekur site in the Arawe Islands of New Britain proved to be younger than expected and raise questions about the starting date for Lapita pottery in the Bismarck Archipelago as a whole. In reviewing the Makekur dates in this broader context, the date lists for the archipelago were culled according to more rigorous rules than have previously been used. This process identified several problematic results where contexts, relevance and interpretations are questioned, and confirmed the problems of calibration of shell dates in the Mussau Islands 
acknowledged by Kirch (2001: Chapter 10). In terms of plant dates, there is a gap between those for the EQS, ERA and FYS sites, and those for other assemblages that should be of similar age on the basis of stylistic studies of the pottery. The reason for this discrepancy is unclear. Several possibilities can be considered:

1. the earliest occupation at Makekur has not yet been dated or excavated;

2. the Makekur dates are correct, and some Lapita pottery sites are indeed much older than others, but we have yet to define adequately the stylistic relationships between their pottery assemblages;

3. older dates reflect in-built age for unidentified charcoal or wood samples, cultural activity predating the introduction of pottery, or old shells from Pre-Lapita contexts.

Which, if any, of these possibilities apply is open to discussion. Option 1 seems unlikely, given the general consistency of dates for Makekur from four laboratories over three decades, though dating of other samples or further excavation could change this picture. Option 2 also seems unlikely, as it would imply that there was an earlier stage of pottery development before the occupation of Makekur that has not yet been recognised. If Option 3 holds, then the starting date for Lapita could be around 3250-3150 cal. BP.

This revised date has several implications. It places the arrival of pottery-making in the archipelago at the late end of the period proposed for the W-K2 eruption, and supports the reoccupation dates for the Willaumez Peninsula and Garua Island proposed by Petrie and Torrence (2008: Tables 5 and 6). It suggests that the interval between the arrival of pottery-making in the archipelago and the dispersal of the pottery-makers into Remote Oceania was short, as the pottery studies indicate. This has ramifications for our understanding of the Lapita phenomenon, as several authors have discussed (e.g. Bedford 2015; Petchey et al. 2015; Summerhayes 2007). On the other hand, questions remain concerning the acceptance or rejection of dates at several key sites, and not the least of these questions concerns appropriate $\Delta \mathrm{R}$ offsets for marine shell samples. Resolution of some questions may be through redating programs that are currently underway (P.V. Kirch pers. comm. 21 February 2017) or are under consideration (G.R. Summerhayes pers. comm. 8 February 2017), or re-excavation of some key sites to obtain short-lived and identified materials from reliable, well-controlled contexts, preferably avoiding marine shells unless reliable, local $\Delta \mathrm{R}$ values directly applicable to each site can be established. In addition, it may be necessary to rethink the current models for the development of Lapita pottery, particularly in light of the opportunities offered by the Lapita Design On-Line Project (Chiu 2011, 2013), that may help resolve some apparent conflicts between dates and stylistic analyses.

Although the dates discussed here are less than an ideal set, they are currently the best we have to work with. Once agreement is reached on a 'clean' set of dates for Lapita sites in the archipelago, a formal Bayesian approach will be possible. In the meantime, it is worth bearing in mind Bronk Ramsey's (2009:339) caution that 'most attempts to analyze ${ }^{14} \mathrm{C}$ dates without a proper formal model give misleading results and is perhaps why, when asked to look at a series of calibrated ${ }^{14} \mathrm{C}$ dates from a single phase, almost everyone will instinctively overestimate their spread'. This may well explain, in part, why the preferred date for the beginning of Lapita pottery has oscillated over the decades.

\section{Acknowledgments}

The additional AMS dates for Makekur were funded by the Australian Institute of Nuclear Science and Engineering (AINSE) through grant ALNGRA15013. We thank AINSE for this support. We also thank Geraldine Jacobsen (Centre for Accelerator Science, Australian Nuclear 
Science and Technology Organisation, Lucas Heights, Australia), Robin Torrence (Australian Museum, Sydney, Australia), Sue Lindsay (formerly Australian Museum, Sydney, Australia), Rachel Wood (Radiocarbon Facility, Research School of Earth Sciences (RSES), The Australian National University (ANU), Canberra, Australia), Wallace Ambrose (Archaeology and Natural History, ANU, Canberra, Australia), Professor Matthew Spriggs (School of Archaeology and Anthropology, ANU, Canberra, Australia), Carol Lentfer (School of Social Sciences, University of Queensland, St Lucia, Brisbane, Australia, and Service de Préhistoire, Université de Liège, Liège, Belgium), Ian Lilley (Aboriginal and Torres Strait Islander Studies Unit, University of Queensland, Brisbane, Australia), Christian Reepmeyer (James Cook University, Cairns, Queensland, Australia), Cameron Petrie (Department of Archaeology and Anthropology, University of Cambridge, UK), Glenn R. Summerhayes (Department of Archaeology and Anthropology, University of Otago, New Zealand), Dimitri Anson (Department of Archaeology and Anthropology, University of Otago, New Zealand), Fiona Petchey (Radiocarbon Dating Laboratory, University of Waikato, Hamilton, New Zealand), Darden Hood (Beta Analytic Inc., Miami, Florida, USA) and Patrick Kirch (Department of Anthropology, University of California, Berkeley, USA) for patiently answering queries, checking facts and providing information. Misuse or distortion of their information and advice is solely the authors responsibility. An anonymous reviewer provided valuable modifications and corrections to the original draft.

\section{References}

Aird, S. 2014. Assessing mid-to-late Holocene predation of Conomurex luhuanus and Tectus niloticus at Lizard Island, northeastern Australia. Unpublished BA (Hons) Thesis. James Cook University, Cairns.

Allen, M.S. and J.M. Huebert 2014. Short-lived plant materials, long-lived trees, and Polynesian ${ }^{14} \mathrm{C}$ dating: Considerations for ${ }^{14} \mathrm{C}$ sample selection and documentation. Radiocarbon 56(1):257-276. doi.org/10.2458/56.16784.

Allen, M.S. and R. Wallace 2007. New evidence from the east Polynesian gateway: Substantive and methodological results from Aitutaki, southern Cook Islands. Radiocarbon 49(3):1163-1179. doi.org/10.1017/S0033822200043095.

Ambrose, W.R. 1973. Obsidian as an indicator of age and contacts at Ambitle Island. Unpublished. Paper presented to the International Quaternary Association (INQUA) Conference, Christchurch, New Zealand.

Ambrose, W.R. and C. Gosden 1991. Investigations on Boduna Island. In J. Allen and C. Gosden (eds), Report of the Lapita Homeland Project, pp. 182-88. Occasional Papers in Prehistory 20. Department of Prehistory, RSPacS, The Australian National University, Canberra.

Anderson, A. 1991. The chronology of colonization in New Zealand. Antiquity 65:767-795. doi.org/ 10.1017/S0003598X00080510.

Anderson, A. 1995. Current approaches to East Polynesian colonisation research. Journal of the Polynesian Society 104(1):110-132.

Anderson, A., T. Higham and R. Wallace. 2001. The radiocarbon chronology of the Norfolk Island archaeological sites. Records of the Australian Museum, Supplement 27:33-42. doi.org/10.3853/j.08127387.27.2001.1337.

Anson, D., R. Walter and R.C. Green 2005. A revised and redated event phase sequence for the ReberRakival Lapita site, Watom Island, East New Britain Province, Papua New Guinea. University of Otago Studies in Prehistoric Anthropology 20. University of Otago, Dunedin. 
Bafmatuk, F., B. Egloff and R. Kaiku 1981. Islanders: Past and present. In K.R. Henderson (ed.), Hemisphere: An Asian-Australian Annual, pp. 77-81. Australian Government Publishing Service, Canberra.

Bayliss, A. 2015. Quality in Bayesian chronological models in archaeology. World Archaeology 47(4):677700. doi.org/10.1080/00438243.2015.1067640.

Bedford, S. 2015. Going beyond the known world 3000 years ago: Lapita exploration and colonization of Remote Oceania. In C. Sand, S. Chiu and N. Hogg (eds), The Lapita Cultural Complex in time and space: Expansion routes, chronologies and typologies, pp. 25-47. Archeologia Pasifika 4. Institut d'archéologie de la Nouvelle-Calédonie et du Pacifique (IANCP), Nouméa.

Bedford, S. and J.-C. Galipaud 2010. Chain of islands: Lapita in the north of Vanuatu. In C. Sand and S. Bedford (eds), Lapita: Ancêtres Océaniens/Oceanic ancestors, pp. 122-137. Musée du quai Branly and Somogy, Paris.

Boyd, W.E., J. Specht and J. Webb 1999. Holocene shoreline change and archaeology on the Kandrian coast of West New Britain, Papua New Guinea. In J. Hall and I.J. McNiven (eds), Australian coastal archaeology, pp. 283-287. Research Papers in Archaeology and Natural History 31. ANH Publications, Canberra.

Bronk Ramsey, C. 2009. Bayesian analysis of radiocarbon dates. Radiocarbon 51(1):337-360. doi.org/ $10.1017 /$ S0033822200033865.

Burley, D., K. Edinborough, M. Weisler and J.-x. Zhao 2015. Bayesian modeling and chronological precision for Polynesian settlement of Tonga. PLoS One 10(3):e0120795. doi.org/10.1371/journal. pone. 0120795 .

Chiu, S. 2011. Lapita-scape: Research possibilities using the digital database of Lapita pottery. People and Culture in Oceania 27:39-63.

Chiu, S. 2013. Digital preservation of the past: The establishment of the online database for the study of Lapita pottery. In S. Chiu and C.-H. Tsang (eds), Archaeology and sustainability, pp. 485-511. Centre for Archaeological Studies, Research Centre of Humanities and Social Sciences. Academia Sinica, Taipei.

Clark, G. and A. Anderson 2009. Site chronology and a review of radiocarbon dates from Fiji. In G. Clark and A. Anderson (eds), The early prehistory of Fiji, pp. 153-182. Terra Australis 31. ANU E Press, Canberra. doi.org/10.22459/TA31.12.2009.07.

Clark, G., F. Petchey, O. Winter, M. Carson and P. O’Day 2010. New radiocarbon dates from the Bapot-1 site in Saipan and Neolithic dispersal by stratified diffusion. Journal of Pacific Archaeology $1(1): 21-35$.

Denham, T., C. Bronk Ramsey and J. Specht 2012. Dating the appearance of Lapita pottery in the Bismarck Archipelago and its dispersal to Remote Oceania. Archaeology in Oceania 47(1):39-46. doi.org/10.1002/j.1834-4453.2012.tb00113.x.

Dye, T. 1994. Apparent ages of marine shells: Implications for archaeological dating in Hawai' i. Radiocarbon 36:51-57. doi.org/10.1017/S0033822200014326.

Dye, T. 2015. Dating human dispersal into Remote Oceania: A Bayesian view from Hawai' i. World Archaeology 47(4):661-676. doi.org/10.1080/00438243.2015.1052845.

Edwards, R.L., J.W. Beck, G.S. Burr, D.J. Donahue, J.M.A. Chappell, A.L. Bloom, E.R.M. Druffel and F.W. Taylor 1993. A large drop in atmospheric C-14/C-12 and reduced melting in the Younger Dryas, documented with Th-230 Ages of Corals. Science 260(5110):962-968. doi.org/10.1126/ science.260.5110.962. 
Fink, D., M. Hotchkis, Q. Hua, G. Jacobsen, A.M. Smith, U. Zoppi, D. Child, C. Mifsud, H. van der Gaast, A. Williams and M. Williams 2004. The ANTARES AMS facility at ANSTO. Nuclear Instruments \& Methods in Physics Research B 223-224:109-115. doi.org/10.1016/j.nimb.2004.04.025.

Galipaud, J.-C. 2010. Makué and Shokraon: Earliest arrivals and cultural transformations in northern Vanuatu. In C. Sand and S. Bedford (eds), Lapita: Ancêtres Océaniens/Oceanic ancestors, pp. 138-139. Musée du quai Branly and Somogy, Paris.

Galipaud, J.-C. and M.C. Swete Kelly 2007. Makué (Aore Island, Santo, Vanuatu): A new Lapita site in the ambit of New Britain obsidian distribution. In S. Bedford, C. Sand and S.P. Connaughton (eds), Oceanic explorations: Lapita and Western Pacific settlement, pp. 151-162. Terra Australis 26. ANU Press, Canberra. doi.org/10.22459/TA26.2007.

Galipaud, J.-C., C. Reepmeyer, R. Torrence, S. Kelloway and P. White 2014. Long-distance connections in Vanuatu: New obsidian characterisations for the Makué site, Aore Island. Archaeology in Oceania 49:110-116. doi.org/10.1002/arco.5030.

Gosden, C. and J. Webb 1994. The creation of a Papua New Guinean landscape: Archaeological and geomorphological evidence. Journal of Field Archaeology 21(1):29-51. doi.org/10.1179/0093469947 91549245.

Gosden, C., J. Webb, B. Marshall and G.R. Summerhayes 1994. Lolmo Cave: A mid to late Holocene site, the Arawe Islands, West New Britain Province, Papua New Guinea. Asian Perspectives 33(1):97-119.

Green, R.C. and M. Jones 2008. The absolute age of SE-RF-6 (Ngamanie) and its relation to SE-RF-2 (Nenumbo): Two decorated Lapita sites in the Southeast Solomon Islands. New Zealand Journal of Archaeology (2007) 29:5-18.

Green, R.C., M. Jones and P.J. Sheppard 2008. The reconstructed environment and absolute dating of SE-SZ-8 Lapita site on Nendö, Santa Cruz, Solomon Islands. Archaeology in Oceania 43(2):49-61. doi.org/10.1002/j.1834-4453.2008.tb00030.x.

Hayes, T.L. 1992. Plant macrofossils from archaeological sites in the Arawe Islands, Papua New Guinea. Unpublished BA (Hons) thesis, La Trobe University, Bundoora.

Hogg, A.G., T.F.G. Higham and J. Dahm 1998. ${ }^{14} \mathrm{C}$ dating of modern marine and estuarine shellfish. Radiocarbon 40(2):975-984. doi.org/10.1017/S0033822200018944.

Hogg, A.G., Q. Hua, P.G. Blackwell, M. Niu, C.E. Buck, T.P. Guilderson, T.J. Heaton, J.G. Palmer, P.J. Reimer, R.W. Reimer, C.S.M. Turney and S.R.H. Zimmerman 2013. SHCal13 Southern Hemisphere calibration, 0-50,000 years cal. BP. Radiocarbon 55(4):1889-1903. doi.org/10.2458/ azu_js_rcc.55.16783.

Hope, G. (ed.) 1998. Identifying wood charcoal remains as palaeo evidence for regions of Central and Northeast Australia. Research Papers in Archaeology and Natural History 28. ANH Publications, RSPAS, The Australian National University, Canberra.

Hua, Q., G. Jacobsen, U. Zoppi, E.M. Lawson, A.A. Williams and M.J. McGann 2001. Progress in radiocarbon target preparation at the ANTARES AMS centre. Radiocarbon 43:275-282. doi.org/ 10.1017/S003382220003811X.

Hua, Q., M. Barbetti, U. Zoppi, D. Fink, M. Watanasak and G. Jacobsen. 2004. Radiocarbon in tropical tree rings during the Little Ice Age. Nuclear Instruments and Methods in Physics Research B 223-224:489-494. doi.org/10.1016/j.nimb.2004.04.092.

InsideWood. 2004-onwards. The InsideWood Database. insidewood.lib.ncsu.edu/search [accessed March 2014]. 
Jones, M., F. Petchey, R.C. Green, P. Sheppard and M. Phelan 2007. The marine $\Delta$ R for Nenumbo: A case study in calculating reservoir offsets from paired sample data. Radiocarbon 49(1):95-102. doi.org/10.1017/S0033822200041928.

Kirch, P.V. 1987. Lapita and Oceanic cultural origins: Excavations in the Mussau Islands, Bismarck Archipelago, 1985. Journal of Field Archaeology 14(2):163-180. doi.org/10.1179/0093469877 92208493.

Kirch, P.V. (ed.) 2001. Lapita and its transformations in Near Oceania: Archaeological investigations in the Mussau Islands, Papua New Guinea, 1985-88. Volume I: Introduction, stratigraphy, chronology. Archaeological Research Facility Contribution No 59. University of California, Berkeley.

Kirch, P.V. and T.L. Hunt 1988. Radiocarbon dates from the Mussau Islands and the Lapita colonization of the Southwest Pacific. Radiocarbon 30(2):161-169. doi.org/10.1017/S0033822200044106.

Kirch, P.V., M.S. Allen, V.L. Butler and T.L. Hunt 1987. Is there an Early Far Western Lapita province? Sample size effects and new evidence from Eloaua Island. Archaeology in Oceania 22(3):123-27. doi.org/10.1002/j.1834-4453.1987.tb00176.x.

Lentfer, C., P.J. Matthews, C. Gosden, S. Lindsay and J. Specht 2013. Prehistory in a nutshell: A Lapita age nut-cracking stone from the Arawe Islands, Papua New Guinea. Archaeology in Oceania 48(3):121-129. doi.org/10.1002/arco.5008.

Lentfer, C., C. Pavlides and J. Specht 2010. Natural and human impacts in a 35 000-year vegetation history in central New Britain, Papua New Guinea. Quaternary Science Reviews 29(27-28): 3750-3567. doi.org/10.1016/j.quascirev.2010.08.009.

Lilley, I. 1986. Prehistoric exchange in the Vitiaz Strait, Papua New Guinea. Unpublished PhD thesis, The Australian National University, Canberra.

Lilley, I. 1991. Lapita and Post-Lapita developments in the Vitiaz Straits-West New Britain area. Bulletin of the Indo-Pacific Prehistory Association 11:313-322. doi.org/10.7152/bippa.v11i0.11395.

Lilley, I. 2002. Lapita and Type Y in the KLK site, Siassi, Papua New Guinea. In S. Bedford, C. Sand and D. Burley (eds), Fifty years in the field: Essays in honour of Richard Shutler Jr's archaeological career, pp. 79-90. New Zealand Archaeological Association Monograph 25. New Zealand Archaeological Association, Auckland.

Lucas, J.S. 1988. Giant clams: Description, distribution and life history. In J.W. Copland and J.S. Lucas (eds), Giant Clams in Asia and the Pacific, pp. 21-32. Australian Centre for International Agricultural Research. Monograph 9, Canberra.

Matthews, P.J. and C. Gosden 1997. Plant remains from waterlogged sites in the Arawe Islands, West New Britain Province, Papua New Guinea: Implications for the history of plant use and domestication. Economic Botany 51(2):121-133. doi.org/10.1007/BF02893102.

McGregor, H.V., M.K. Gagan, M.T. McCulloch, E. Hodge and G. Mortimer 2008. Mid-Holocene variability in the marine ${ }^{14} \mathrm{C}$ reservoir for northern coastal Papua New Guinea. Quaternary Geochronology 3(3):213-225. doi.org/10.1016/j.quageo.2007.11.002.

Noury, A. and J.-C. Galipaud 2011. Les Lapita: Nomades du Pacifique. IRD Éditions, Marseille. doi.org/ 10.4000/books.irdeditions.653.

Nunn, P.D. and F. Petchey 2013. Bayesian re-evaluation of Lapita settlement in Fiji: Radiocarbon analysis of the Lapita occupation at Bourewa and nearby sites on the Rove Peninsula, Viti Levu Island. Journal of Pacific Archaeology 4(2):21-34.

Oteng-Amoako, A.A. 1990. Macroscopic wood identification manual for New Guinea timbers. Forest Research Institute Publication 1. Lae, Papua New Guinea: Forest Research Institute. 
Oteng-Amoako, A.A. 1992. Photomicrographic atlas of Papua New Guinea timbers with IAWA microscopic hardwood identification features. Forest Research Institute Publication 3. Madang, Papua New Guinea: Forest Research Unit.

Petchey F. 2009. Dating marine shell in Oceania: Issues and prospects. In A. Fairbairn, S. O'Connor and B. Marwick (eds), New directions in archaeological science, pp. 157-172. Terra Australis 28. ANU E Press, Canberra. doi.org/10.22459/TA28.02.2009.

Petchey, F. and G. Clark 2010. A marine reservoir correction value $(\Delta R)$ for the Palauan archipelago: Environmental and oceanographic considerations. Journal of Island and Coastal Archaeology 5(2):236252. doi.org/10.1080/15564890903155935.

Petchey, F. and S. Ulm 2012. Marine reservoir variation in the Bismarck region: An evaluation of spatial and temporal change in $\Delta \mathrm{R}$ and $R$ over the last 3000 years. Radiocarbon 54(1):45-58. doi.org/10.2458/ azu_js_rc.v54i1.13050.

Petchey, F., M. Phelan and P. White 2004. New $\Delta$ R values for the Southwest Pacific Ocean. Radiocarbon 46(2):1005-1014. doi.org/10.1017/S0033822200036079.

Petchey, F., R.C. Green, M. Jones and M. Phelan 2005. A local marine reservoir correction value $(\Delta R)$ for Watom Island, Papua New Guinea. New Zealand Journal of Archaeology 26(2004):29-40.

Petchey, F., A. Anderson, A. Hogg and A. Zondervan 2008. The marine reservoir effect in the Southern Ocean: An evaluation of extant and new $\Delta \mathrm{R}$ values and their application to archaeological chronologies. Journal of the Royal Society of New Zealand 38(4):243-262. doi.org/10.1080/03014220809510559.

Petchey, F., S. Ulm, B. David, I.J. McNiven, B. Asmussen, H. Tomkins, N. Dolby, K. Aplin, T. Richards, C. Rowe, M. Leavesley and H. Mandui 2012a. High-resolution radiocarbon dating of marine materials in archaeological contexts: Radiocarbon marine reservoir variability between Anadara, Gafrarium, Batissa, Polymesoda spp. and Echinoidea at Caution Bay, southern coastal Papua New Guinea. Archaeological and Anthropological Sciences 5:69-80. doi.org/10.1007/s12520-012-0108-1.

Petchey, F., S. Ulm, B. David, I.J. McNiven, B. Asmussen, H. Tomkins, T. Richards, C. Rowe, M. Leavesley, H. Mandui and J. Stanisic 2012b. ${ }^{14} \mathrm{C}$ Marine reservoir variability in herbivores and deposit-feeding gastropods from an open coastline, Papua New Guinea. Radiocarbon 54(3-4): 967-978. doi.org/10.1017/S0033822200047603.

Petchey, F., M. Spriggs, S. Bedford, F. Valentin and H.R. Buckley 2014. Radiocarbon dating of burials from the Teouma Lapita cemetery, Efate, Vanuatu. Journal of Archaeological Science 50:227-242. doi.org/10.1016/j.jas.2014.07.002.

Petchey, F., M. Spriggs, S. Bedford and F. Valentin 2015. The chronology of occupation at Teouma, Vanuatu: Use of a modified chronometric hygiene protocol and Bayesian modeling to evaluate midden remains. Journal of Archaeological Science: Reports 4:95-105. doi.org/10.1016/j.jasrep. 2015.08.024.

Petrie, C.A. and R. Torrence 2008. Assessing the effects of volcanic disasters on human settlement in the Willaumez Peninsula, Papua New Guinea: A Bayesian approach to radiocarbon calibration. The Holocene 18(5):729-744. doi.org/10.1177/0959683608091793.

Pineda, R. and J.-C. Galipaud 1998. Évidences archéologiques d'une surrection différentielle de l'île de Malo (Archipel du Vanuatu) au cours de l'Holocène récent. Comptes-Rendus de l'Académie des Sciences 327:777-779. doi.org/10.1016/S1251-8050(99)80050-0. 
Reimer, P.J., E. Bard, A. Bayliss, J.W. Beck, P.G. Blackwell, C. Bronk Ramsey, C.E. Buck, H. Cheng, R.L. Edwards, M. Friedrich, P.M. Grootes, T.P. Guilderson, D.L. Hoffmann, A.G. Hogg, K.A. Hughen, K.F. Kaiser, B. Kromer, S.W. Manning, M. Niu, Reimer, D.A. Richards, E.M. Scott, J.R. Southon, R.A. Staff, C.S.M. Turney and J. van der Plicht 2013. IntCal13 and Marine13 radiocarbon age calibration curves 0-50,000 years cal BP. Radiocarbon 55:1869-1887. doi.org/10.2458/azu_js_rc.55.16947.

Rick, T.C., R.L. Vellanoweth and J.M. Erlandson 2005. Radiocarbon dating and the 'old shell' problem: Direct dating of artifacts and cultural chronologies in coastal and other aquatic regions. Journal of Archaeological Science 32:1641-1648. doi.org/10.1016/j.jas.2005.05.005.

Rieth, T.M. and J.S. Athens 2017. Late Holocene human expansion into Near and Remote Oceania: A Bayesian model of the chronologies of the Mariana Islands and Bismarck Archipelago. Journal of Island and Coastal Archaeology, online 7 June 2017. doi.org/10.1080/15564894.2017.1331939.

Sheppard, P.J. 2011. Lapita colonization across the Near/Remote Oceania boundary. Current Anthropology 52(6):799-840. doi.org/10.1086/662201.

Sheppard, P.J., S. Chiu and R. Walter 2015. Re-dating Lapita movement into Remote Oceania. Journal of Pacific Archaeology 6(1):26-36.

Specht, J. 2007. Small islands in the big picture. In S. Bedford, C. Sand and S.P. Connaughton (eds), Oceanic explorations: Lapita and Western Pacific settlement, pp. 51-70. Terra Australis 26. ANU E Press, Canberra. doi.org/10.22459/TA26.2007.

Specht, J. and C. Gosden 1997. Dating Lapita pottery in the Bismarck Archipelago, Papua New Guinea. Asian Perspectives 36(2):175-199.

Specht, J. and G.R. Summerhayes 2007. The Boduna Island (FEA) Lapita site, Papua New Guinea. In J. Specht and V. Attenbrow (eds), Archaeological studies of the middle and late Holocene, Papua New Guinea, Part II, pp. 51-103. Technical Reports of the Australian Museum 20. Australian Museum, Sydney. doi.org/10.3853/j.1835-4211.20.2007.1474.

Specht, J., and R. Torrence 2007a. Pottery sites of the Talasea area, Papua New Guinea. In J. Specht and V. Attenbrow (eds), Archaeological studies of the middle and late Holocene, Papua New Guinea, Part IV, pp. 131-196. Technical Reports of the Australian Museum 20. Australian Museum, Sydney. doi.org/ 10.3853/j.1835-4211.20.2007.1476.

Specht, J. and R. Torrence 2007b. Lapita all over: Land-use on the Willaumez Peninsula, Papua New Guinea. In S. Bedford, C. Sand and S.P. Connaughton (eds), Oceanic explorations: Lapita and Western Pacific settlement, pp. 71-96. Terra Australis 26. ANU E Press, Canberra. doi.org/10.22459/ TA26.2007.

Specht, J., R. Fullagar and R. Torrence 1991. What was the significance of Lapita pottery at Talasea? Bulletin of the Indo-Pacific Prehistory Association 11:281-294. doi.org/10.7152/bippa.v11i0.11392.

Specht, J., T. Denham, J. Goff and J.E. Terrell 2014. Deconstructing the Lapita Cultural Complex in the Bismarck Archipelago. Journal of Archaeological Research 22(2):89-140. doi.org/10.1007/s10814013-9070-4.

Spriggs, M. 1989. The dating of the Island Southeast Asian Neolithic: An attempt at chronometric hygiene and linguistic correlation. Antiquity 63:587-613. doi.org/10.1017/S0003598X00076560.

Spriggs, M. 1990. Dating Lapita: Another view. In M. Spriggs (ed.), Lapita design, form and composition: Proceedings of the Lapita Design Workshop, Canberra, December 1988, pp. 6-27. Occasional Papers in Prehistory 19. Department of Prehistory, RSPacS, The Australian National University, Canberra. 
Spriggs, M. 1996. Chronology and colonisation in Island Southeast Asia and the Pacific: New data and an evaluation. In J.M. Davidson, G. Irwin, B.F. Leach, A. Pawley and D. Brown (eds), Oceanic culture history: Essays in honour of Roger Green, pp. 33-50. New Zealand Journal of Archaeology Special Publication, Auckland.

Spriggs, M. 2003. Chronology of the Neolithic transition in Island Southeast Asia and the Western Pacific: A view from 2003. The Review of Archaeology 24(2):57-80.

Spriggs, M. and A.J. Anderson 1993. Late colonization of East Polynesia. Antiquity 67:200-217. doi.org/10.1017/S0003598X00045324.

Stuiver, M. and T.F. Braziunas 1993. Modeling atmospheric ${ }^{14} \mathrm{C}$ influences and ${ }^{14} \mathrm{C}$ ages of marine samples to 10,000 BC. Radiocarbon 35(1):137-189. doi.org/10.1017/S0033822200013874.

Stuiver, M. and H. Polach 1977. Discussion: Reporting of ${ }^{14} \mathrm{C}$ data. Radiocarbon 19(3):355-363. doi.org/10.1017/S0033822200003672.

Summerhayes, G.R. 2000. Lapita interaction. Terra Australis 15. Department of Archaeology and Natural History and the Centre for Archaeological Research, The Australian National University, Canberra.

Summerhayes, G.R. 2001a. Defining the chronology of Lapita in the Bismarck Archipelago. In G.R. Clark, A.J. Anderson and T. Sorovi-Vunidilo (eds), The archaeology of Lapita dispersal in Oceania: Papers from the Fourth Lapita Conference, June 2000, Canberra, Australia, pp. 25-38. Terra Australis 17. Pandanus Books, The Australian National University, Canberra.

Summerhayes, G.R. 2001b. Far western, western, and eastern Lapita: A re-evaluation. Asian Perspectives 39(1-2):109-118. doi.org/10.1353/asi.2000.0013.

Summerhayes, G.R. 2007. The rise and transformation of Lapita in the Bismarck Archipelago. In S. Chiu and C. Sand (eds), From Southeast Asia to the Pacific: Archaeological perspectives on the Austronesian expansion and the Lapita Cultural Complex, pp. 141-169. Centre for Archaeological Studies, Research Centre of Humanities and Social Sciences. Academic Sinica, Taipei.

Summerhayes, G.R. 2010. Lapita interaction: An update. In M. Gadu and H.-m. Lin (eds), 2009 International Symposium on Austronesian Studies, pp. 11-40. National Museum of Prehistory, Taitong, Taiwan.

Summerhayes, G.R., E. Matisoo-Smith, H. Mandui, J. Allen, J. Specht, N. Hogg and S. McPherson 2010. Tamuarawai (EQS): An Early Lapita site on Emirau, New Ireland, PNG. Journal of Pacific Archaeology 1(1):62-75.

Tanaka, N., M.C. Monaghan and D.M. Rye 1986. Contribution of metabolic carbon to mollusc and barnacle shell carbonate. Nature 320:520-523. doi.org/10.1038/320520a0.

Thaman, R.R., L.A.J. Thomson, R. Demeo, F. Arecki and C.R. Elevitch 2006. Intsia bijuga (vesi), ver. 3.1. In C.R. Elevitch (ed.), Species profiles for Pacific Island agroforestry. Pacific Agricultural resources, Holualoa, HA. www.traditionaltree.org [accessed 4 May 2009].

Torrence, R. 2016. Social resilience and long-term adaptation to volcanic disasters: The archaeology of continuity and innovation in the Willaumez Peninsula, Papua New Guinea. Quaternary International 394:6-16. doi.org/10.1016/j.quaint.2014.04.029.

Torrence, R. and C.M. Stevenson 2000. Beyond the beach: Changing Lapita landscapes on Garua Island, Papua New Guinea. In A. Anderson and T. Murray (eds), Australian archaeologist: Collected papers in honour of Jim Allen, pp. 324-345. Coombs Academic Publishing, The Australian National University, Canberra. 
Wheeler, E. 2011. InsideWood: A web resource for hardwood anatomy. IAWA Journal 32(2):199-211. doi.org/10.1163/22941932-90000051.

White, J.P. and M.-N. Harris 1997. Changing sources: Early Lapita period obsidian in the Bismarck Archipelago. Archaeology in Oceania 32(1):97-107. doi.org/10.1002/j.1834-4453.1997.tb00375.x.

White, J.P., C. Coroneos, V. Neall, W. Boyd and R. Torrence 2002. FEA site, Boduna Island: Further investigations. In S. Bedford, C. Sand and D. Burley (eds), Fifty years in the field: Essays in honour and celebration of Richard Shutler Jr's archaeological career, pp. 101-107. New Zealand Archaeological Association Monograph 25. New Zealand Archaeological Association, Auckland.

Yonge, C.M. 1967. Form, habit and evolution in the Chamidae (Bivalvia) with reference to conditions in the Rudists (Hippuritacea). Philosophical Transactions of the Royal Society of London, Series B, Biological Sciences 252 (775):49-105. doi.org/10.1098/rstb.1967.0003.

\section{Appendix 9.1. Culling the dates}

This appendix provides a commentary on the dates considered for inclusion in this chapter, with explanations why they were accepted or rejected. Each entry is identified by its site code in the site register at the National Museum and Art Gallery of Papua New Guinea, with the first letter of the three- or four-letter code indicating the province:

- $\mathrm{E}=\mathrm{New}$ Ireland Province

- $\mathrm{F}=$ West New Britain Province

- $\mathrm{K}=$ Morobe Province

- $S=$ East New Britain Province.

Strict application of the principles of 'chronometric hygiene' (Spriggs 1989) and 'chronometric flossing' (Kirch 2001:204) to the date lists would have eliminated several important sites that must be early on stylistic grounds. This would have reduced the number of accepted dates to 11, making the dataset 'uncomfortably small' (Allen and Wallace 2007:1177). Some dates that perhaps should be rejected are indicated as Accepted with reservations; this applies to all marine shell dates.

\section{Plant}

Table 9A.1. Mussau Islands, New Ireland.

\begin{tabular}{|c|c|}
\hline $\mathrm{ECA}$ & $\begin{array}{l}\text { GX-5498: 3030 } 180 \text {. Accepted with reservations; unidentified charcoal, context unclear. From the same 'oven' } \\
\text { as GX-5499, which is much older. Kirch (2001:73) questions whether this was an 'oven' and suggests the } \\
\text { charcoal was embedded in cemented coral and sand. }\end{array}$ \\
\hline $\mathrm{ECA}$ & $\begin{array}{l}\text { GX-5499: } 3900 \pm 260 \text {. Rejected; unidentified charcoal from the same 'oven' as the much younger GX-5498. } \\
\text { The calibrated date is far too old to be relevant. }\end{array}$ \\
\hline $\begin{array}{l}\text { ECA/Airfield } \\
\text { transect }\end{array}$ & $\begin{array}{l}\text { ANU-5080: } 3260 \pm 90 \text {. Accepted with reservations; unidentified charcoal from the base of the cultural layer } \\
\text { and top of the palaeobeach. The early date may reflect old wood or in-built age (Kirch 2001:223) or possibly } \\
\text { a pre-pottery combustion event-see main text. }\end{array}$ \\
\hline $\mathrm{ECA} / \mathrm{B}$ & $\begin{array}{l}\text { ANU-5075: 2370 } \pm 120 \text {. Rejected; fine flecks of unidentified, dispersed charcoal, too young. One of } \\
\text { three samples from zone } 11 \text { which is described as 'probably after the abandonment of the stilt-house' } \\
\text { (Kirch 2001:224-225). The result is best viewed as an averaged age, but of what is unclear. }\end{array}$ \\
\hline $\mathrm{ECA} / \mathrm{B}$ & 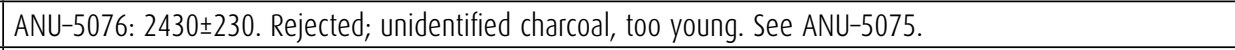 \\
\hline $\mathrm{ECA} / \mathrm{B}$ & 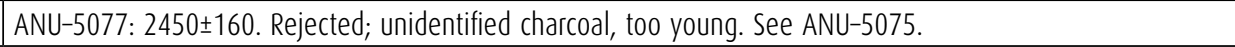 \\
\hline $\mathrm{ECA} / \mathrm{B}$ & $\begin{array}{l}\text { ANU-5078: } 2600 \pm 160 \text {. Rejected; combined sample of fine flecks of unidentified, dispersed charcoal from } \\
\text { two excavation units in Zone C2-3, 'probably after the abandonment of the stilt house' (Kirch 2001:225). } \\
\text { The result is best viewed as an averaged age, but of what is unclear. }\end{array}$ \\
\hline
\end{tabular}




\begin{tabular}{|c|c|}
\hline $\mathrm{ECA} / \mathrm{B}$ & $\begin{array}{l}\text { ANU-5079: } 2840 \pm 115 \text {. Rejected; unidentified charcoal. Combined sample of fine flecks of dispersed charcoal } \\
\text { from two excavation units in Zone } 11 \text {. See ANU-5075. }\end{array}$ \\
\hline $\mathrm{ECA} / \mathrm{B}$ & $\begin{array}{l}\text { ANU-5790: } 2950 \pm 80 \text {. Accepted; Post B1, culturally modified wood of Intsia bijuga (Colebr.) 0. Kuntze, } \\
\text { one of three main corner posts of the Area B stilt structure. }\end{array}$ \\
\hline $\mathrm{ECA} / \mathrm{B}$ & $\begin{array}{l}\text { ANU-5791: 2930 } \pm 80 \text {. Accepted; Post B2, culturally modified wood of Intsia bijuga (Colebr.) 0. Kuntze, second } \\
\text { of three main corner posts of the Area B stilt structure. As its maximum diameter is c. } 180 \mathrm{~mm} \text { (Kirch 2001: } \\
\text { Table 4.2), the sample probably has little-to-moderate in-built age. }\end{array}$ \\
\hline $\mathrm{ECA} / \mathrm{B}$ & $\begin{array}{l}\text { Beta-20451: 2950 } \pm 70 \text {. Accepted with reservations; short-lived coconut (Cocos nucifera L.) endocarp. } \\
\text { The recovery context was in the 'muck zone' lacking artefacts but with charcoal and plant remains } \\
\text { (Kirch 2001:86, 224). It is unclear what is being dated. }\end{array}$ \\
\hline $\mathrm{ECA} / \mathrm{B}$ & $\begin{array}{l}\text { Beta-20452: } 3050 \pm 70 \text {. Accepted; stake or Post B30 of unidentified, culturally modified wood from basal } \\
\text { Zone C3. Probably has little in-built age as its maximum diameter is } 30 \mathrm{~mm} \text { (Kirch 2001: Table 4.2). }\end{array}$ \\
\hline ECA/W250 & $\begin{array}{l}\text { Beta-30681: } 2860 \pm 60 \text {. Accepted with reservations; post of unidentified, culturally modified wood with } \\
\text { unknown potential for in-built age. }\end{array}$ \\
\hline ECA/W250 & $\begin{array}{l}\text { Beta-30682: 2970 } \pm 50 \text {. Accepted with reservations; 'structural beam' of unidentified, culturally modified wood } \\
\text { with unknown potential for in-built age (Kirch 2001:229). }\end{array}$ \\
\hline ECA/W250 & 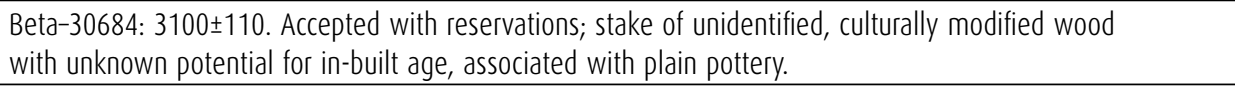 \\
\hline $\mathrm{ECA} / \mathrm{C}$ & $\begin{array}{l}\text { Beta-30686: 2850 } \pm 70 \text {. Accepted; stake or Post C3 of Diospyros sp. wood, culturally modified. From the earlier } \\
\text { of two occupation phases in Area C that are thought to post-date the stilt house of Area B (Kirch 2001:230). } \\
\text { The result is older than Beta-30687 from the second construction phase in Area C, and slightly younger than } \\
\text { some Area B dates. The stake probably has little in-built age as its maximum diameter is } 60 \mathrm{~mm} \text { (Kirch 2001: } \\
\text { Table 4.2). }\end{array}$ \\
\hline $\mathrm{ECA} / \mathrm{C}$ & $\begin{array}{l}\text { Beta-30687: 2600 } \pm 60 \text {. Rejected; Post C20 of Intsia bijuga wood; too young. This sample came from the } \\
\text { second phase of construction in Area C, which is later than Area B (Kirch 2001:230). See Beta-30686. }\end{array}$ \\
\hline $\mathrm{ECB}$ & $\begin{array}{l}\text { Beta-20453: } 3200 \pm 70 \text {. Rejected; unidentified charcoal that received incomplete chemical pre-treatment; } \\
\text { unknown potential for in-built age (Kirch 2001:139, 231). This is the oldest calibrated plant date of the } \\
\text { Mussau series other than ANU-5080 at ECA. Petchey and Ulm (2012: Table 2, footnote h) reject the sample } \\
\text { on the basis that it was unidentified charcoal and not confirmed as a short-lived specimen. }\end{array}$ \\
\hline
\end{tabular}

Source: Bafmatuk et al. 1981; Kirch 2001: Chapter 10; Petchey and Ulm 2012.

Table 9A.2. Emirau Island, New Ireland.

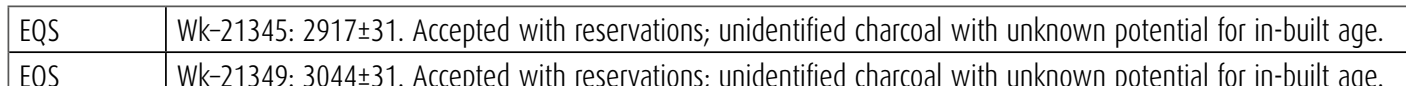

Source: Summerhayes et al. 2010: Table 1.

Table 9A.3. Anir Islands, New Ireland.

\begin{tabular}{|c|c|}
\hline ERA & 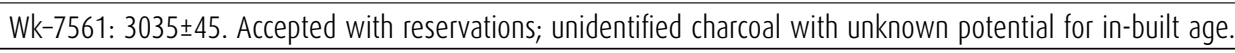 \\
\hline ERA & Wk-7563: 3075 \pm 45 . Accepted with reservations; unidentified charcoal with unknown potential for in-built age. \\
\hline ERA & 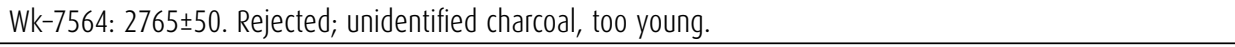 \\
\hline EAQ & 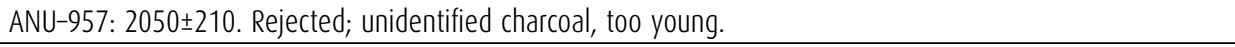 \\
\hline EAQ & $\begin{array}{l}\text { ANU-11193: } 3220 \pm 170 \text {. Rejected; unidentified charcoal with unknown potential for in-built age. The calibrated } \\
\text { result is too old at the upper range limit, perhaps reflecting a Pre-Lapita level, as the sample context is } \\
\text { described as 'just below the main cultural-bearing layer' (Summerhayes 2001a:34). }\end{array}$ \\
\hline EAQ & $\begin{array}{l}\text { ANU-11190: } 2110 \pm 240 \text {. Rejected; unidentified charcoal from a reworked sediment, too young. The sample } \\
\text { possibly relates to a Post-Lapita volcanic event (Summerhayes 2001a:34). }\end{array}$ \\
\hline ERD & 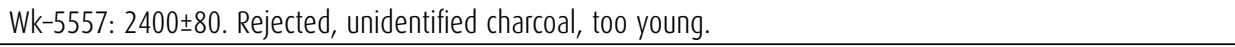 \\
\hline ERG & $\begin{array}{l}\text { ANU-11191: } 3090 \pm 170 \text {. Accepted with reservations; unidentified charcoal with unknown potential } \\
\text { for in-built age. }\end{array}$ \\
\hline
\end{tabular}

Source: Ambrose 1973; Summerhayes 2001a: Table 1. 
Table 9A.4. Duke of York Islands, New Britain.

\begin{tabular}{|l|l|}
\hline SEP & $\begin{array}{l}\text { SUA-3062: 2730 } \\
\text { Harris 1997: Rejected; unidentified charcoal that the excavator assigns to a late context (White and }\end{array}$ \\
\hline
\end{tabular}

Source: White and Harris 1997: Table 1.

Table 9A.5. Watom Island, New Britain.

\begin{tabular}{|l|l|}
\hline SAC & Wk-7370: 2860 \pm 60. Accepted; short-lived endocarp of coconut (Cocos nucifera L.).
\end{tabular}

Source: Anson et al. 2005: Table 6.

Table 9A.6. Garua Island, New Britain.

\begin{tabular}{|c|c|}
\hline FAO & NZA-3738: 2439ะ64. Rejected; unidentified nut endocarp, probably Canarium sp.; too young. \\
\hline FAO & NZA-3729: 2452ะ67. Rejected; unidentified nut endocarp, probably Canarium sp.; too young. \\
\hline FAQ & $\begin{array}{l}\text { Beta-72140: } 2540 \pm 60 \text {. Rejected; unidentified nut endocarp, probably Canarium sp.; no pottery association, } \\
\text { too young. }\end{array}$ \\
\hline FQY & Beta-72141: 2580ะ60. Rejected; unidentified nut endocarp, probably Canarium sp.; too young. \\
\hline FAAN & 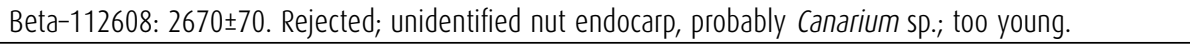 \\
\hline FAAQ & 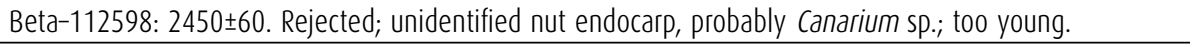 \\
\hline FSZ & $\begin{array}{l}\text { NZA-6099: } 2781 \pm 68 \text {. Rejected; unidentified nut endocarp, probably Canarium sp.; calibrated age exceeds } \\
3000 \text { years only at } 20 \text {. The pottery from FSZ is very fragmented and the site appears to be disturbed. } \\
\text { The associated pottery does not look 'early' (Specht and Torrence 2007a: Figures 10-13). }\end{array}$ \\
\hline FYS & $\begin{array}{l}\text { NZA-3733: 2883ะ64. Accepted; unidentified nut endocarp, probably Canarium sp.; associated with plain } \\
\text { pottery. }\end{array}$ \\
\hline FYS & $\begin{array}{l}\text { Beta-72144: } 3060 \pm 60 \text {. Accepted; unidentified nut endocarp, probably Canarium sp.; associated with one } \\
\text { dentate-stamped sherd. }\end{array}$ \\
\hline FYS & $\begin{array}{l}\text { NZA-3734: } 3030 \pm 69 \text {. Accepted with reservations; unidentified nut endocarp, probably Canarium sp.; } \\
\text { no pottery at this level. }\end{array}$ \\
\hline
\end{tabular}

Source: Specht and Torrence 2007a: Table 5; Torrence and Stevenson 2000: Table 1.

Table 9A.7. Willaumez Peninsula, New Britain.

\begin{tabular}{|c|c|}
\hline FAAH & $\begin{array}{l}\text { Wk-10463: 2880 } \pm 59 \text {. Accepted; short-lived, unidentified nut endocarp, probably Canarium sp.; associated with } \\
\text { dentate-stamped pottery. }\end{array}$ \\
\hline FAAH & $\begin{array}{l}\text { Wk-19190: } 2847 \pm 34 \text {. Accepted; short-lived, unidentified nut endocarp, probably Canarium sp.; associated with } \\
\text { dentate-stamped pottery. }\end{array}$ \\
\hline FACQ & 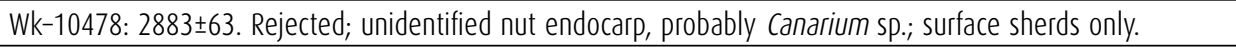 \\
\hline FACR & 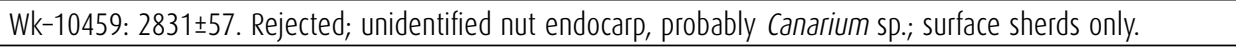 \\
\hline FADA & Wk-12840: 2965ะ46. Rejected; unidentified nut endocarp, probably Canarium sp.; no pottery associated. \\
\hline FADC & $\begin{array}{l}\text { Wk-12845: } 2936 \pm 47 \text {. Accepted; unidentified nut endocarp, probably Canarium sp.; plain pottery only. } \\
\text { Incorrectly listed as } 2963 \pm 47 \text { in Table } 3 \text { of Specht and Torrence 2007b. }\end{array}$ \\
\hline
\end{tabular}

Source: Specht and Torrence 2007b: Table 3.

Table 9A.8. Arawe Islands New Britain.

\begin{tabular}{|l|l|}
\hline FOH & Wk-8539: $3740 \pm 60$. Rejected; unidentified charcoal with unknown in-built age, too old. \\
\hline FOH & Beta-54164: 2640 \pm 90 . Rejected; unidentified charcoal with unknown in-built age, too young. \\
\hline FOH & $\begin{array}{l}\text { Beta-54165: } 2850 \pm 80 . \text { Accepted with reservations; unidentified charcoal with unknown in-built age, } \\
\text { but consistent with short-lived sample 0zS476. }\end{array}$ \\
\hline FOH & $\begin{array}{l}\text { Beta-54166: } 2730 \pm 70 . \text { Rejected; unidentified charcoal with unknown in-built age, too young. Although } \\
\text { the CRA is identical to SUA-3062 for SEP in the Duke of York Islands, the smaller standard error keeps the } \\
\text { calibrated age below } 3000 \text { years. }\end{array}$ \\
\hline FOH & ANU-11186: $2800 \pm 110$. Accepted with reservations; unidentified charcoal with unknown in-built age. \\
\hline
\end{tabular}




\begin{tabular}{|c|c|}
\hline $\mathrm{FOH}$ & $\begin{array}{l}\text { ANU-11187: } 2730 \pm 100 \text {. Rejected; unidentified charcoal with unknown in-built age. The calibrated result yields } \\
\text { a range limit over } 3000 \text { years at } 20 \text {. In contrast, samples Beta-54166 and Wk-32734 with the same age } \\
\text { have smaller standard errors that restrict their ranges to below } 3000 \text { years. }\end{array}$ \\
\hline $\mathrm{FOH}$ & 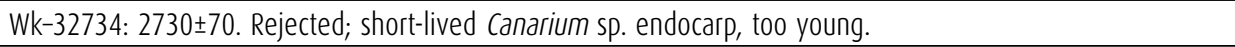 \\
\hline $\mathrm{FOH}$ & 0ZS476: 2860 20 . Accepted; short-lived Canarium sp. endocarp. \\
\hline $\mathrm{FOH}$ & $\begin{array}{l}\text { OZS477: } 2830 \pm 25 \text {. Rejected; wood of cf. Terminalia catappa L.; small standard error keeps the calibrated age } \\
\text { range below } 3000 \text { years. }\end{array}$ \\
\hline $\mathrm{FOH}$ & 0ZS479: 2690 25 . Rejected; short-lived Canarium sp. endocarp; too young. \\
\hline FOL & 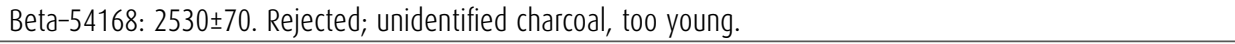 \\
\hline
\end{tabular}

Source: Gosden and Webb 1994; Gosden et al. 1994; Specht and Gosden 1997: Appendix 1; Summerhayes 2001a: Table 3, 2010: Table 2; this chapter.

\section{Shell}

Shell dates ANU-5081 to ANU-5089 were originally issued with an assumed $\delta^{13} \mathrm{C}=0.0 \%$, but in 2000 Matthew Spriggs (pers. comm. to J.S., 17 February 2016) obtained measured values (except for ANU-5081) from John Chappell (then RSES, ANU). Spriggs forwarded the revised $\delta^{13} \mathrm{C}$ values to Kirch, but they arrived too late for inclusion in Kirch's analysis of the Mussau dates, where they were listed as a 'Note added in proof' (Kirch 2001:236). Spriggs (2003: Table 1) used some of the revised results in a review of dates from Island Southeast Asia and the western Pacific Islands. The measured $\delta^{13} \mathrm{C}$ values and adjusted dates are listed below:

Table 9A.9. Measured $\delta^{13} \mathrm{C}$ values and adjusted dates.

\begin{tabular}{|l|l|l|l|}
\hline ANU Lab code & Age reported in Kirch 2001 & Measured $\delta^{13}$ C value & $\delta^{13}$-adjusted CRA \\
\hline ANU-5081 & $3010 \pm 80$ & $n / a$ & No change \\
\hline ANU-5082 & $2950 \pm 80$ & $1.7 \pm 0.2 \% 00$ & $2950 \pm 80$ \\
\hline ANU-5083 & $2810 \pm 80$ & $1.9 \pm 0.2 \% 00$ & $2840 \pm 70$ \\
\hline ANU-5084 & $3190 \pm 80$ & $2.3 \pm 0.2 \% 0$ & $3230 \pm 70$ \\
\hline ANU-5085 & $3130 \pm 80$ & $2.0 \pm 0.2 \% 0$ & $3170 \pm 70$ \\
\hline ANU-5086 & $3120 \pm 80$ & $1.6 \pm 0.2 \% 0$ & $3140 \pm 70$ \\
\hline ANU-5087 & $3150 \pm 80$ & $1.4 \pm 0.2 \% 00$ & $3170 \pm 70$ \\
\hline ANU-5088 & $3470 \pm 90$ & $2.4 \pm 0.2 \% 00$ & $3510 \pm 90$ \\
\hline ANU-5089 & $3380 \pm 90$ & $2.4 \pm 0.2 \%$ & $3420 \pm 90$ \\
\hline
\end{tabular}

Source: Author's summary.

The $\delta^{13} \mathrm{C}$-adjusted CRAs are used in Table 9A.10. The ANU dates for the KLK site in the Siassi Islands were calculated on measured $\delta^{13} \mathrm{C}$ values (Lilley 1986: Appendix 1), and those for Boduna (FEA) on $\delta^{13} \mathrm{C}=0.0 \pm 2.0 \%$ (Rachel Wood, RSES, ANU, pers. comm. to J.S., 10 February 2016). All shell dates are listed as 'accepted with reservations' even where there is a calculated local $\Delta \mathrm{R}$ value, to reflect the issues discussed in the text surrounding marine shell as a dating medium.

Table 9A.10. Mussau Islands, New Ireland: Calibrated with $\Delta R=-293 \pm 92$ (Petchey and Ulm 2012: Figure 1).

\begin{tabular}{|c|c|}
\hline $\mathrm{ECA} / \mathrm{A}$ & 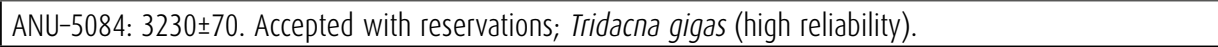 \\
\hline $\mathrm{ECA} / \mathrm{A}$ & $\begin{array}{l}\text { ANU-5085: } 3170 \pm 70 \text {. Accepted with reservations; Hyotissa hyotis (medium to high reliability?). The recovery } \\
\text { context was Layer IIB, near the base of square W229/N100 (Kirch 2001:85). As the bottom of the cultural } \\
\text { deposit was not reached, the sample refers to an unknown point in time after initial occupation. }\end{array}$ \\
\hline $\mathrm{ECA} / \mathrm{B}$ & $\begin{array}{l}\text { ANU-5081: } 3010 \pm 80 \text {. Rejected; Tridacna gigas (high reliability) associated with post stumps in zone C3. } \\
\text { The status of the sample's } \delta^{13} \mathrm{C} \text { value is unclear. As the sample was used to calculate a } \Delta R \text { value for Area B } \\
\text { (Kirch 2001:200-201), the date cannot be calibrated using that value or that of }-293 \pm 92 \text { years (Petchey and } \\
\text { Ulm 2012: Figure 1) as the calibrated age would not be an independent determination. }\end{array}$ \\
\hline
\end{tabular}




\begin{tabular}{|c|c|}
\hline $\mathrm{ECA} / \mathrm{B}$ & $\begin{array}{l}\text { ANU-5082: } 2950 \pm 80 \text {. Rejected; Hyotissa hyotis (medium to high reliability?) associated with post stumps in } \\
\text { zone C3. This shell was associated with post stumps in zone C3 (Kirch 2001:226) and was used to calculate } \\
\text { the } \Delta R \text { value for Area B (Kirch 2001:200). See ANU-5081. }\end{array}$ \\
\hline $\mathrm{ECA} / \mathrm{B}$ & $\begin{array}{l}\text { ANU-5083: } 2810 \pm 80 \text {. Rejected; Hyotissa hyotis (medium to high reliability?), too young; the sample context } \\
\text { (zone B1) post-dates initial site occupation (Kirch 2001:226). }\end{array}$ \\
\hline $\mathrm{ECA} / \mathrm{B}$ & $\begin{array}{l}\text { Beta-30673: } 3110 \pm 70 \text {. Rejected; Spondylus sp. (medium or high reliability) from zone C1. The sample } \\
\text { does not refer to an early stage of pottery as it came from 'the upper portion of Zone C' (Kirch 2001:227). } \\
\text { See Beta-30674, Beta-30675. }\end{array}$ \\
\hline ECA/W250 & 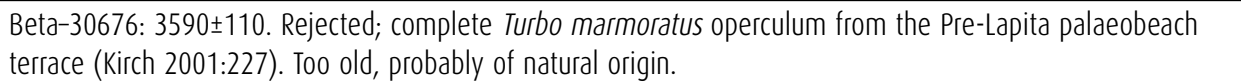 \\
\hline ECA/W250 & $\begin{array}{l}\text { Beta-30677: } 3170 \pm 70 \text {. Accepted with reservations; Spondylus sp. (medium or high reliability) 'from the } \\
\text { elevated palaeobeach terrace' (Kirch 2001:227). }\end{array}$ \\
\hline ECA/W250 & $\begin{array}{l}\text { Beta-30678: 3190 } \pm 80 \text {. Accepted with reservations; Chama sp. (medium or high reliability) with an 'artificially } \\
\text { chipped ventral margin' from the 'foreshore slope of the palaeobeach terrace' (Kirch 2001:228). }\end{array}$ \\
\hline ECA/W250 & 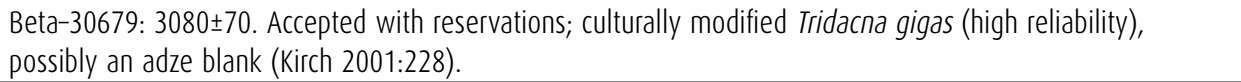 \\
\hline ECA/W250 & $\begin{array}{l}\text { Beta-30680: } 3320 \pm 80 \text {. Rejected; Chama sp. (medium or high reliability). The sample came from above } \\
\text { a slightly younger post stump (Beta-30681). The calibrated age is too old (3664-3370 cal. BP) and Kirch } \\
\text { (2001:228) suggests that the sample was 'possibly older shell incorporated into deposit?' }\end{array}$ \\
\hline ECA/W250 & 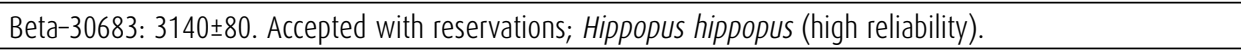 \\
\hline $\mathrm{ECA} / \mathrm{C}$ & $\begin{array}{l}\text { Beta-30674: } 3110 \pm 70 \text {. Rejected; Hippopus hippopus (high reliability). The sample was 'associated with } \\
\text { the earlier of two occupation phases' in Area C, which should be later than Area B (Kirch 2001:229), } \\
\text { yet Beta-30674 is the same age as Beta-30675 and Beta-30673 (Spondylus) from Area B zone C1. } \\
\text { Compare with wood date Beta-30686 for Post C3. }\end{array}$ \\
\hline $\mathrm{ECA} / \mathrm{C}$ & $\begin{array}{l}\text { Beta-30675: } 3110 \pm 80 \text {. Rejected; culturally modified Tridacna derasa (high reliability) 'associated with the } \\
\text { earlier of two phases of stilt-house occupation' in Area C that should be later than Area B (Kirch 2001:230). } \\
\text { See Beta-30674. }\end{array}$ \\
\hline $\mathrm{ECA} / \mathrm{C}$ & $\begin{array}{l}\text { Beta-30685: 2770 } \pm 70 \text {. Rejected; Hyotissa hyotis (medium to high reliability?), too young. This sample } \\
\text { belongs to the later phase of construction in Area C with incised pottery (Kirch 2001:230). }\end{array}$ \\
\hline $\mathrm{ECB}$ & $\begin{array}{l}\text { ANU-5086: } 3140 \pm 70 \text {. Rejected; Hyotissa hyotis (medium to high reliability?). The sample was used with Beta- } \\
20453 \text { (charcoal) to calculate a } \Delta R \text { value for ECB (Kirch 2001:201-203). Using this to calibrate ANU-5086 would } \\
\text { yield a result dependent on Beta-24053, which is rejected as it did not receive full chemical pre-treatment. }\end{array}$ \\
\hline $\mathrm{ECB}$ & $\begin{array}{l}\text { ANU-5087: 3170 } \pm 70 \text {. Rejected; Hyotissa hyotis (medium to high reliability?). See ANU-5086 regarding } \\
\text { calibration. }\end{array}$ \\
\hline EHB & $\begin{array}{l}\text { ANU-5088: 3510 } \pm 90 \text {. Rejected; Tridacna gigas found with finely dentate-stamped sherds. The recovery } \\
\text { context is described as 'extensively penetrated' by land crab burrows, and the layer as having 'no meaningful } \\
\text { internal stratification' (Kirch 2001:141). The dated shell could be of natural origin displaced by crab burrowing. }\end{array}$ \\
\hline EHB & $\begin{array}{l}\text { ANU-5089: } 3420 \pm 90 \text {. Rejected; Hyotissa hyotis (medium to high reliability?) found with finely dentate- } \\
\text { stamped sherds. See ANU-5088. }\end{array}$ \\
\hline EKE & $\begin{array}{l}\text { Beta-30693: } 3420 \pm 70 \text {. Rejected; Hippopus hippopus (high reliability). Calibration yields an improbable range } \\
\text { for the start of Lapita pottery, though Kirch (2001:216) notes that it is 'not inconsistent with the shell dates } \\
\text { from the paleobeach terrace at ECA'. However, the sample context is suspect-see main text. }\end{array}$ \\
\hline EKO & $\begin{array}{l}\text { Beta-25669: } 3200 \pm 70 \text {. Accepted with reservations; culturally modified body whorl of Turbo marmoratus } \\
\text { (medium reliability). }\end{array}$ \\
\hline EKQ & $\begin{array}{l}\text { Beta-20454: } 3280 \pm 70 \text {. Rejected; mixed sample of unidentified shell fragments that could have different } \\
\text { reliability levels and derive from different periods. }\end{array}$ \\
\hline EKQ & Beta-21789: 3030ะ80. Rejected; mixed sample of identified and unidentified species. See Beta-20454. \\
\hline EKQ & $\begin{array}{l}\text { Beta-25670: } 3270 \pm 80 \text {. Accepted with reservations; two culturally modified shells of Tridacna maxima } \\
\text { (high reliability) and Turbo marmoratus (medium reliability). }\end{array}$ \\
\hline EKQ & $\begin{array}{l}\text { Beta-25671: } 3190 \pm 90 \text {. Accepted with reservations; three complete and four fragments of Conomurex } \\
\text { luhuanus (medium reliability). }\end{array}$ \\
\hline
\end{tabular}

Source: Kirch 2001: Chapter 10; Spriggs 2003: Table 1. 
Table 9A.11. Anir Islands, New Ireland: Calibrated with the local $\Delta R=-69 \pm 51$ years (Summerhayes 2007:154, note iii).

\begin{tabular}{|l|l|}
\hline ERA & $\begin{array}{l}\text { Wk-7560: } 3260 \pm 45 . \text { Rejected; mixed sample of Conus Sp. (low reliability) and Tridacna sp. (high reliability). } \\
\text { This sample was used with Beta-7561 (charcoal) to calculate a local } \Delta R \text { value for ERA and does not provide } \\
\text { an independent calibrated determination. }\end{array}$ \\
\hline ERA & $\begin{array}{l}\text { Wk-7562: } 3350 \pm 45 . \text { Rejected; mixed sample of Turbo sp. (medium reliability) and Tridacna sp. (high reliability). } \\
\text { This sample was used with Beta-7563 (charcoal) to calculate a local } \Delta R \text { value for ERA; see Wk-7560. }\end{array}$ \\
\hline ERD & Wk-7556: $2810 \pm 50$. Rejected; unidentified shell, too young. \\
\hline ERD & $\begin{array}{l}\text { Wk-7558: } 3245 \pm 45 . \text { Accepted with reservations; Turbo sp. (medium reliability) and unidentified shell. As this } \\
\text { sample was stratigraphically below and older than the first pottery in the cave, it provides a maximum age } \\
\text { for pottery at this site. }\end{array}$ \\
\hline
\end{tabular}

Source: Summerhayes 2001a: Table 3; Summerhayes 2010: Table 2.

Table 9A.12. Duke of York Islands, New Britain: Calibrated with the local $\Delta R=43 \pm 68$ years (Petchey et al. 2004).

\begin{tabular}{|l|l|}
\hline SDP & $\begin{array}{l}\text { SUA-3061: } 2940 \pm 60 . \text { Rejected; possibly Tridacna gigas (high reliability), too young to be relevant to the start } \\
\text { of Lapita pottery. }\end{array}$ \\
\hline SET & $\begin{array}{l}\text { SUA-3063: } 3030 \pm 60 \text {. Rejected; possibly Tridacna gigas (high reliability), too young to be relevant to the start } \\
\text { of Lapita pottery. }\end{array}$ \\
\hline SET & $\begin{array}{l}\text { SUA-3064: } 3150 \pm 60 . \text { Rejected; possibly Tridacna gigas (high reliability), too young to be relevant to the start } \\
\text { of Lapita pottery. }\end{array}$ \\
\hline SEE & $\begin{array}{l}\text { SUA-3082: } 3090 \pm 60 . \text { Rejected; Conomurex luhuanus (medium reliability), too young to be relevant to the } \\
\text { start of Lapita pottery. }\end{array}$ \\
\hline
\end{tabular}

Source: White and Harris 1997:100.

Table 9A.13. Watom Island, New Britain.

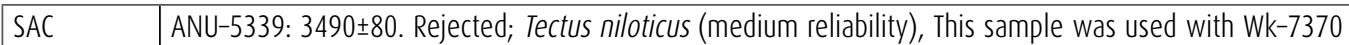
(coconut endocarp) to calculate a $\Delta R$ value for Watom Island, and so calibration with this value would not provide an independent determination. The sample's relationship to Lapita pottery is uncertain as Anson et al. (2005: Table 6) attribute the shell to both Zone C2 and to the Pre-Lapita zone D.

Source: Anson et al. 2005: Table 6; Petchey et al. 2005.

Table 9A.14. Boduna Island, New Britain: Calibrated using $\Delta R=45 \pm 19$ years for Kimbe Bay (Petchey and Ulm 2012: Figure 1).

\begin{tabular}{|c|c|}
\hline FEA & 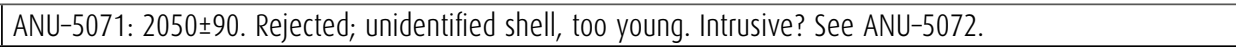 \\
\hline FEA & $\begin{array}{l}\text { ANU-5072: } 3090 \pm 80 \text {. Rejected; unidentified shell. The result is 1200-1000 years older than ANU-5071 from } \\
\text { the same context, but statistically the same as ANU-5073 from a slightly higher context. }\end{array}$ \\
\hline FEA & 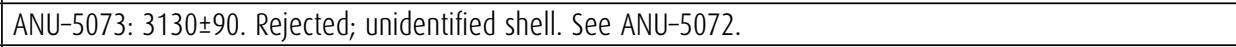 \\
\hline FEA & $\begin{array}{l}\text { Beta-41578: } 3330 \pm 60 \text {. Accepted with reservations; Chama sp. (medium or high reliability) from the base } \\
\text { of the site. }\end{array}$ \\
\hline FEA & $\begin{array}{l}\text { Wk-9936: 3211 } \pm 52 \text {. Rejected; Anadara sp. (medium/high reliability) embedded in beach rock that includes } \\
\text { sherds and obsidian flakes. The temporal relationship between the sample and cultural materials is unknown. }\end{array}$ \\
\hline
\end{tabular}

Source: Ambrose and Gosden 1991; Specht and Summerhayes 2007: Table 1; White et al. 2002: Table 2, 105.

Table 9A.15. Kove Islands, New Britain: Calibrated using Region $5 \Delta R=40 \pm 19$ years (Petchey and Ulm 2012: Figure 1).

\begin{tabular}{|l|l|}
\hline FCL & $\begin{array}{l}\text { Beta-26259: 2990 } \pm 80 . \text { Rejected; Tridacna sp. (high reliability) from 'culturally-sterile basal sediment' of } \\
\text { 'organic mud and sand-coral debris' within the groundwater (Lilley 1991:316). Deposit is extensively } \\
\text { disturbed, and the date is too young to be relevant. }\end{array}$ \\
\hline FPA & $\begin{array}{l}\text { SUA-2822: } 3100 \pm 120 . \text { Rejected; described as 'degraded marine mollusc shell, probably Tridacna sp.' found in } \\
\text { 'dark brown, clayey volcanic ash over cemented coralline sand'. As SUA-2822 was found above Beta-26261 } \\
\text { and ANU-2823, which are both older, it is not relevant to the start of pottery in the Kove Islands. }\end{array}$ \\
\hline
\end{tabular}




\begin{tabular}{|l|l|}
\hline FPA & $\begin{array}{l}\text { ANU-2823: 3220 } \\
\text { (high reliability), found in 'dark brown clayey volcanic ash over cemented coralline sand' below ANU-2822. }\end{array}$ \\
\hline FPA & $\begin{array}{l}\text { Beta-26261: } 3280 \pm 70 . \text { Accepted with reservations; Tridacna sp. (high reliability) from the surface of the } \\
\text { cemented basal sand. Thought to date the 'culturally-sterile basal sediment at FPA' (Lilley 1991:316), } \\
\text { thus providing a maximum age for Lapita pottery on the island. }\end{array}$ \\
\hline
\end{tabular}

Source: Lilley 1991: Table 1; Ian Lilley pers. comm.

Table 9A.16. Tuam Island, Siassi Islands: Calibrated using Region $2 \Delta R=273 \pm 216$ years (Petchey and Ulm 2012: Figure 1).

\begin{tabular}{|l|l|}
\hline KLK & $\begin{array}{l}\text { ANU-4610: 3870 } \\
\text { basal sand, it probably represents a pre-settlement beach shell. }\end{array}$ \\
\hline KLK & ANU-4617: $3010 \pm 80$. Rejected; unidentified shell, too young. \\
\hline KLK & ANU-4620: $3040 \pm 70$. Rejected; unidentified shell, too young. \\
\hline KLK & $\begin{array}{l}\text { ANU-4621: } 3300 \pm 80 . \text { Rejected; unidentified shell. The result conflicts with ANU-4664 from a comparable } \\
\text { context; p0ssibly non-cultural in origin? }\end{array}$ \\
\hline KLK & ANU-4664: $3000 \pm 100$. Rejected; probable Tridacna sp. (high reliability) adze; too young. \\
\hline
\end{tabular}

Source: Lilley 1986:126-130, Appendix 1; Lilley 2002: Table 1.

Table 9A.17. Arawe Islands, New Britain: Calibrated using $\Delta R=273 \pm 216$ years for Region 2 (Petchey and Ulm 2012: Figure 1).

\begin{tabular}{|c|c|}
\hline FNY & $\begin{array}{l}\text { Beta-27940: } 2870 \pm 70 \text {. Rejected; 'oyster' shell, too young. The reported age was not } \delta^{13} \text { C-adjusted, and there } \\
\text { is uncertainty about the disturbed nature of FNY trenches (Gosden and Webb 1994). }\end{array}$ \\
\hline FOF & $\begin{array}{l}\text { Beta-26644: } 3530 \pm 70 \text {. Rejected; Anadara antiquata (medium/high reliability). The reported age was not } \delta^{13} \mathrm{C}- \\
\text { adjusted and the result is stratigraphically inconsistent (Gosden et al. 1994). }\end{array}$ \\
\hline $\mathrm{FOH}$ & $\begin{array}{l}\text { Beta-27946: } 3200 \pm 70 \text {. Rejected; 'oyster' shell. The reported age was not } \delta^{13} C \text {-adjusted. The pottery record } \\
\text { sheets for the sample context suggest that no pottery was found in this level. }\end{array}$ \\
\hline $\mathrm{FOH}$ & 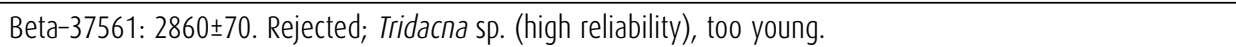 \\
\hline $\mathrm{FOH}$ & $\begin{array}{l}\text { Beta-55323: } 3230 \pm 70 \text {. Rejected; unidentified shell, the upper limit of the calibrated age falls below } 3000 \\
\text { years. The reported age was not } \delta^{13} C \text {-adjusted and was originally published as } 2800 \pm 70 \text { (Specht and Gosden } \\
\text { 1997: Appendix 1). The adjusted age (Summerhayes 2001a:32, Table 3) is cited here. }\end{array}$ \\
\hline $\mathrm{FOH}$ & 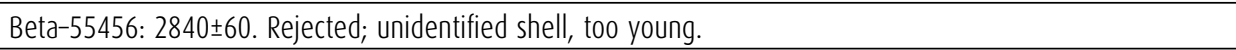 \\
\hline F0) & 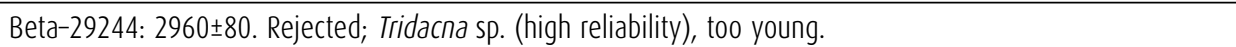 \\
\hline FOJ & $\begin{array}{l}\text { Beta-29245: } 3230 \pm 50 \text {. Rejected; Tridacna sp. (high reliability), the upper limit of the calibrated age falls } \\
\text { below } 3000 \text { years. }\end{array}$ \\
\hline
\end{tabular}

Source: Specht and Gosden 1997: Table 1 and 3; Summerhayes 2001a: Table 3; see also this chapter Table 9.3.

Table 9A.18. Kandrian, New Britain: As there is no calculated $\Delta R$ value relevant to the Kandrian region, all samples are rejected.

\begin{tabular}{|c|c|}
\hline FFS & 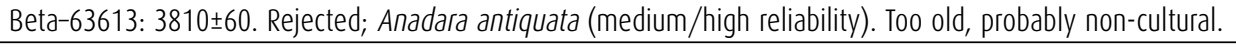 \\
\hline FLF & $\begin{array}{l}\text { Beta-57767: } 3170 \pm 70 \text {. Rejected; Anadara antiquata shells (medium/high reliability), associated with dentate- } \\
\text { stamped pottery. }\end{array}$ \\
\hline FLF & $\begin{array}{l}\text { Beta-63616: 3430 } \pm 80 \text {. Rejected; Anadara antiquata shells (medium/high reliability), some burnt. There is } \\
\text { uncertainty about the suitability of burnt shell for dating (Clark et al. 2010:26). }\end{array}$ \\
\hline FLQ & 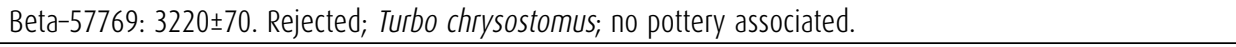 \\
\hline FLQ & 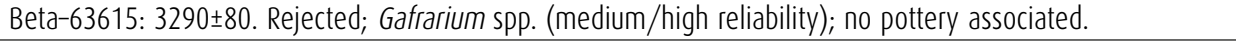 \\
\hline
\end{tabular}

Source: Boyd et al. 1999: Table 1; Lentfer et al. 2010: Table 4; Specht and Gosden 1997: Appendix 1. 
This text is taken from Debating Lapita: Distribution, Chronology, Society and Subsistence, edited by Stuart Bedford and Matthew Spriggs, published 2019 by ANU Press,

The Australian National University, Canberra, Australia.

doi.org/10.22459/TA52.2019.09 